\title{
CHANGING CENOZOIC BARRIERS AND THE AUSTRALIAN PALEOBOTANICAL RECORD ${ }^{1}$
}

\author{
Helene A. Martin ${ }^{2}$
}

\begin{abstract}
The first part of this study reconstructs the changing Cenozoic environment of continental drift, tectonics, and climate. The northward movement of Australia brought it into collision with Southeast Asia in Miocene time. Throughout the Cenozoic, New Zealand has remained in approximately the same relative position and the same distance from Australia. Tectonics within Australia have been minor, gentle, and the main topographic features have probably existed in much the same form all through the Cenozoic.

The climate of the early Tertiary was wetter and warmer than that of today, and although the start of desiccation is debated, the present degree of aridity has existed only since the late Pliocene. In the Quaternary, glaciation has been restricted to very small areas in Australia and the glacial periods were more arid than the interglacials. Sea levels have changed throughout the Tertiary as well as the Quaternary. Today, the arid center of the continent is the major feature of the climate. Soils are generally low in fertility, and have been low all through the Cenozoic, when some soils may have been even less fertile than those of today.

In the vegetation today, there are small and disjunct areas of closed forest (= rainforest) in the better watered northern and eastern coastal regions. Eucalyptus dominated forests and scrublands cover the major area. Grasslands and shrublands are found in the arid center.

The second half presents the paleobotanical record of all reliable identifications of macro- and micro-fossils, first appearances and the quantitative relationships of the abundant pollen groups. The vegetation must have been closed forest for most of the Tertiary. The nature of these closed forests changes, but open forests only start developing in the Pliocene. The first evidence of grasslands is found in the Miocene of Central Australia, and open savannah and/or grasslands became dominant in southeastern Australia in the Pleistocene. The vegetation was not necessarily more uniform than that seen today, for there is considerable evidence of geographic and time-related variation in the Tertiary floras.
\end{abstract}

The Quaternary shows cyclic changes of a more open and drier kind of vegetation in glacial periods and a more forested, wetter vegetation in the interglacials.

A comparison of the Australian and New Zealand paleobotanical records shows a general similarity. A number of fossil taxa appear first in Australia and later in New Zealand. The paleoclimate of both has been similar, and distance has not been an insurmountable barrier. The paleobotanical record of Southeast Asia is different, and limited migrations after the Miocene are probably associated with uplift. During the Miocene, there is an increase in Myrtaceae in both Australia and Southeast Asia. It is thought that new availability of soils of low fertility is the cause of this increase in Southeast Asia, whereas both low soil fertility and the developing aridity has been responsible for the increase in Australia.

Climate is the most important environmental factor, for the paleobotanical and paleoclimatic records usually go together. Climate has probably not been a barrier within Australia for most of the Cenozoic, when habitats suitable for closed forest existed in Central Australia, although not necessarily continuous. Some drier areas have probably existed long before the development of the present degree of aridity, allowing adaptations of the flora to develop before these conditions became widespread. Within Australia, tectonics and topography have not been barriers, although they have been important in maintaining habitat diversity. These factors may have been more important as barriers between Australia and Southeast Asia.

This study shows a complex, continuously changing, interwoven environment and flora, rather than migrations stopped or permitted by changing barriers. The concepts of barriers and migrations

${ }^{1}$ This paper was presented at the symposium "Plant Geographical Results of Changing Cenozoic Barriers"' at the XIII International Botanical Congress, Sydney, Australia, 1981. I am indebted to D. T. Blackburn, D. C. Christophel, A. P. Kershaw and colleagues, R. T. Lange, J. Muller, A. D. Partridge, E. M. Truswell, and L. J. Webb and colleagues, who have read the manuscript and offered constructive criticisms.

${ }^{2}$ School of Botany, The University of New South Wales, P.O. Box 1, Kensington, New South Wales, Australia 2033.

Ann. Missouri Bot. Gard. 69: 625-667. 1982. 
come from historical biogeography, and they seem inappropriate in this study, which essentially follows paleoecological principles.

\section{INTRODUCTION}

Areas unfavorable to the growth of plant species constitute barriers to the spread of those species. Fosberg (1963) separates most barriers into the categories of water, topography, climate, and vegetation. Distance may also be regarded as a temporary barrier. Soils, an important factor in Australian phytogeography, may constitute a barrier also. During the Cenozoic, continental drift changes the barriers of water and distance. Tectonic uplift changes topography and climate has been changing continuously. The flora and vegetation have also been changing continuously throughout the Cenozoic. By the beginning of the Cenozoic, the time under consideration in this symposium, the angiosperms had diversified greatly and were a major element in all floras. However, there has been much evolutionary change since the beginning of the Cenozoic, with the appearance of new taxa and extinction of old taxa.

The first part of this paper presents the Cenozoic environment, which is a necessary background to understanding the paleobotanical record. Because a plant taxon requires a suitable environment for growth, its distribution is, for the greater part, controlled by the environment, of which climate is the most important single factor. Some distributions may be adequately explained by a single environmental factor, but frequently a combination of factors produces a more satisfactory explanation. Fossil plants may be used as indicators of past climates. If paleoclimate is reconstructed in such a way and then used to explain past distributions, it would lead to a circular argument. Consequently, the paleoclimate must be reconstructed from independent evidence. Paleobotanical evidence is not admitted here although other biological evidence is admissable. This part of the paper reconstructs the paleogeography, tectonic changes and paleoclimate through the Cenozoic. An attempt is made to reconstruct changes in soil fertility but the evidence available for this is very limited.

In the second part of this paper, the Australian paleobotanical record is presented and possible reasons for changes discussed. The paleobotanical record of New Zealand and Southeast Asia is compared with that of Australia to test the effect of distance as a barrier. Finally, the effectiveness of the barriers discussed above are assessed.

\section{The Cenozoic Environment}

\section{PALEOGEOGRAPHY}

The break-up of Gondwanaland is well known and only movements directly related to Australia and its nearest neighbors are reiterated here.

Separation of Australia from Antarctica commenced at the end of the Paleocene with the formation of a narrow strait, but it was the mid-Oligocene before a deep water channel was formed between the two continents. Australia has moved north some $27^{\circ}$ of latitude during the Tertiary (Fig. 1) (McElhinny, 1970; Crook, 1981; Powell et al., 1981). 

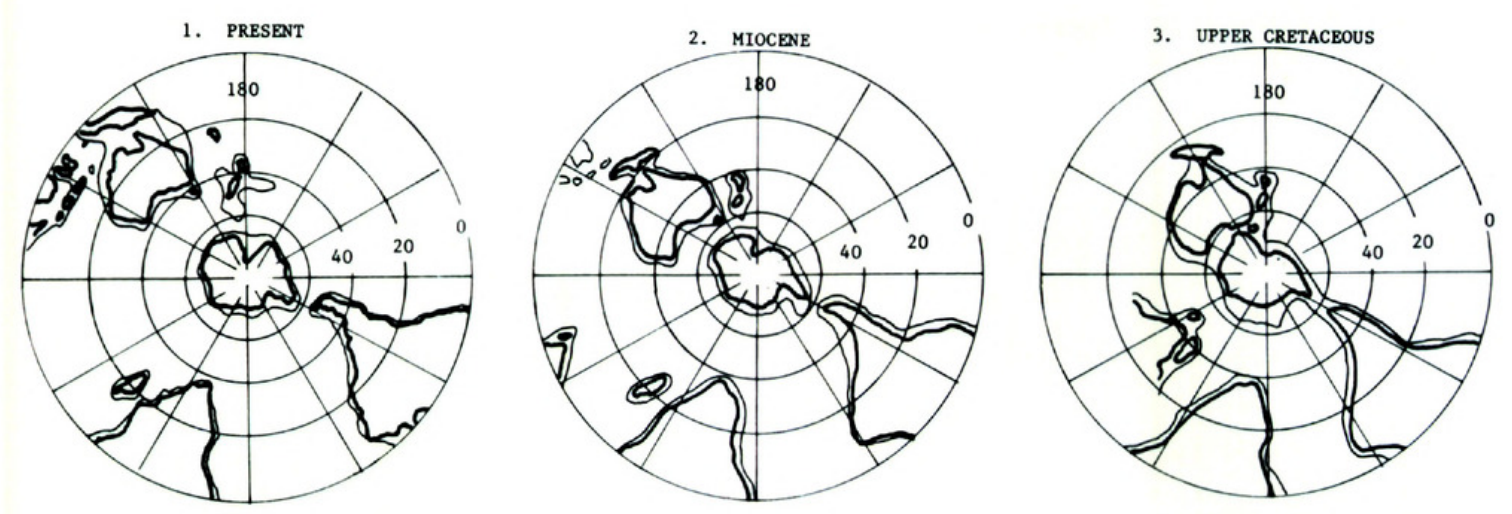

FIgURE 1. Paleogeography showing the relationships of Australia to other continents in the southern hemisphere during the Tertiary. For more detail of the relationships with New Zealand, see Fig. 2 and with Southeast Asia, see Fig. 3.

At the beginning of the late Cretaceous, New Zealand, New Caledonia, and the Lord Howe Rise were closer to each other and to Australia. The opening of the Tasman Sea and the New Caledonian Basin in the late Cretaceous moved these regions further apart. They have remained at approximately the same distance from each other and from Australia for the whole of the Cenozoic (Fig. 2). The distance between Australia and New Zealand is about 2,000 km (Crook \& Belbin, 1978; Coleman, 1980; Crook, 1981).

To the north, southern New Guinea has always been part of the Australian plate. The Banda Arcs are very complex and include some fragments from New Guinea. Parts of Timor originate from the Australian continent (Hamilton, 1979). In the early Tertiary, about $3,000 \mathrm{~km}$ of deep ocean separated the northern edge of the Australian plate from the southern edge of Southeast Asia. The Australian plate came into collision with the Sunda Arcs of Southeast Asia in Miocene time ( 15 million years ago). Southeast Asia was probably 2-3,000 km further east and has moved westward, starting about 20 million years ago, but it has always been at the same latitude as the present (Fig. 3) (Powell \& Johnson, 1980; Powell et al., 1981).

These movements described above simply present the changing spatial relationships through time, and the latitudinal change of the Australian plate has been the most important (see paleoclimate). Continental drift should not be considered in isolation from other environmental factors that may be more important for biogeography (McGowran, 1979). Climate is the most important environmental factor and there have been global changes throughout the Cenozoic, quite apart from the effect of the changing latitude of Australia. These other environmental factors are presented below.

\section{TECTONICS}

Tectonically, the Australian continent has been relatively stable throughout the Cenozoic. Timing of uplift of the Southeastern Highlands is controversial (Bishop \& Young, 1980; Wellman, 1980). One school of thought considers that uplift was well advanced by the early Tertiary and was virtually completed by 
LAND MASS BOUNDARIES

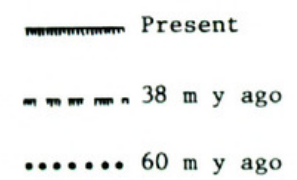

CONTINENTAL BOUNDARIES

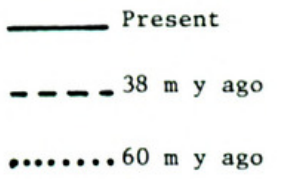

BOUNDARIES HAVE NOT BEEN REDRAWN IF THERE HAS BEEN LITTLE OR NO CHANGE

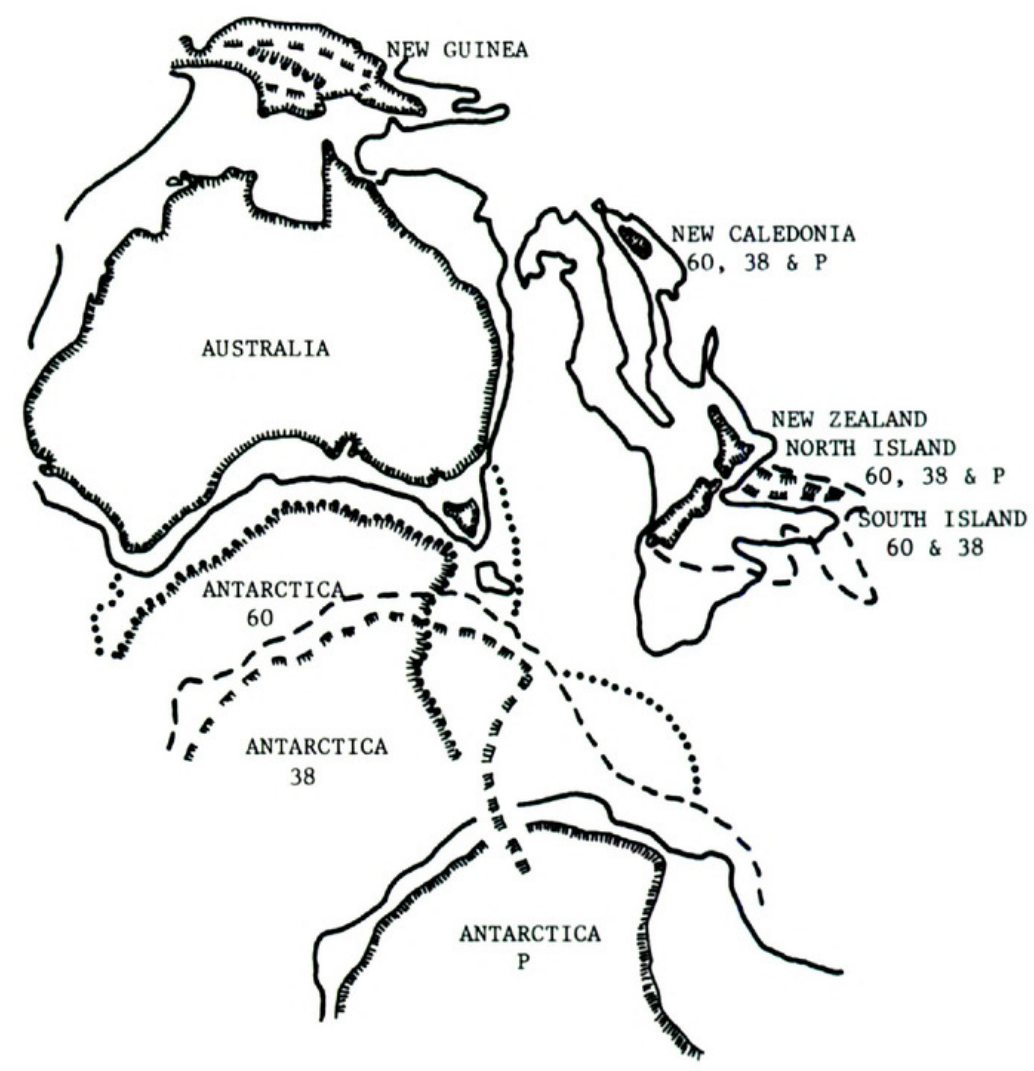

Figure 2. Changes in the distance of New Zealand and Antarctica in relation to Australia, constructed from Crook, 1981. Australia is treated as fixed. The boundary of Antarctica for 60 and 38 million years and the present show increasing distance between the two continents. New Zealand has remained at approximately the same distance of $2,000 \mathrm{~km}$ from Australia. New Caledonia and New Guinea have remained in approximately the same position, relative to Australia.

Oligocene time (Young, 1977). Another school of thought concludes that uplift has been going on continuously at a steady rate all through the Tertiary (Wellman, 1979). Uplift in the east, in South Australia, and in the west has been going on in stages during this time, and is probably still going on, as indicated by the occasional earthquake. There has been subsidence in central Australia and upwarping of parts of Western Australia. A series of lakes in central Australia was fed by the great internal drainage system. Shallow seas encroached from parts of the western and southern coasts but these marginal basins have been only slightly disturbed. All of these movements have been episodic, relatively small, and moderate (Brown et al., 1968; Ollier, 1977). Relief may have been higher in the early Tertiary (e.g., Young, 1977) but was probably not substantially greater than the present in the late Cenozoic (Galloway \& Kemp, 1981). Various lines of evidence suggest that upland areas and drainage patterns of the early to mid-Tertiary were much the same as those of today (Nix, 1981). Australia is a low, flat land mass with most of the relief less than $1,000 \mathrm{~m}$. The highest point, Mt. Kosciusko, is $2,228 \mathrm{~m}$.

\section{PALEOCLIMATE}

Continental movement has had a major effect on climate through the initiation of the circumpolar current. With Australia and South America attached to Ant- 


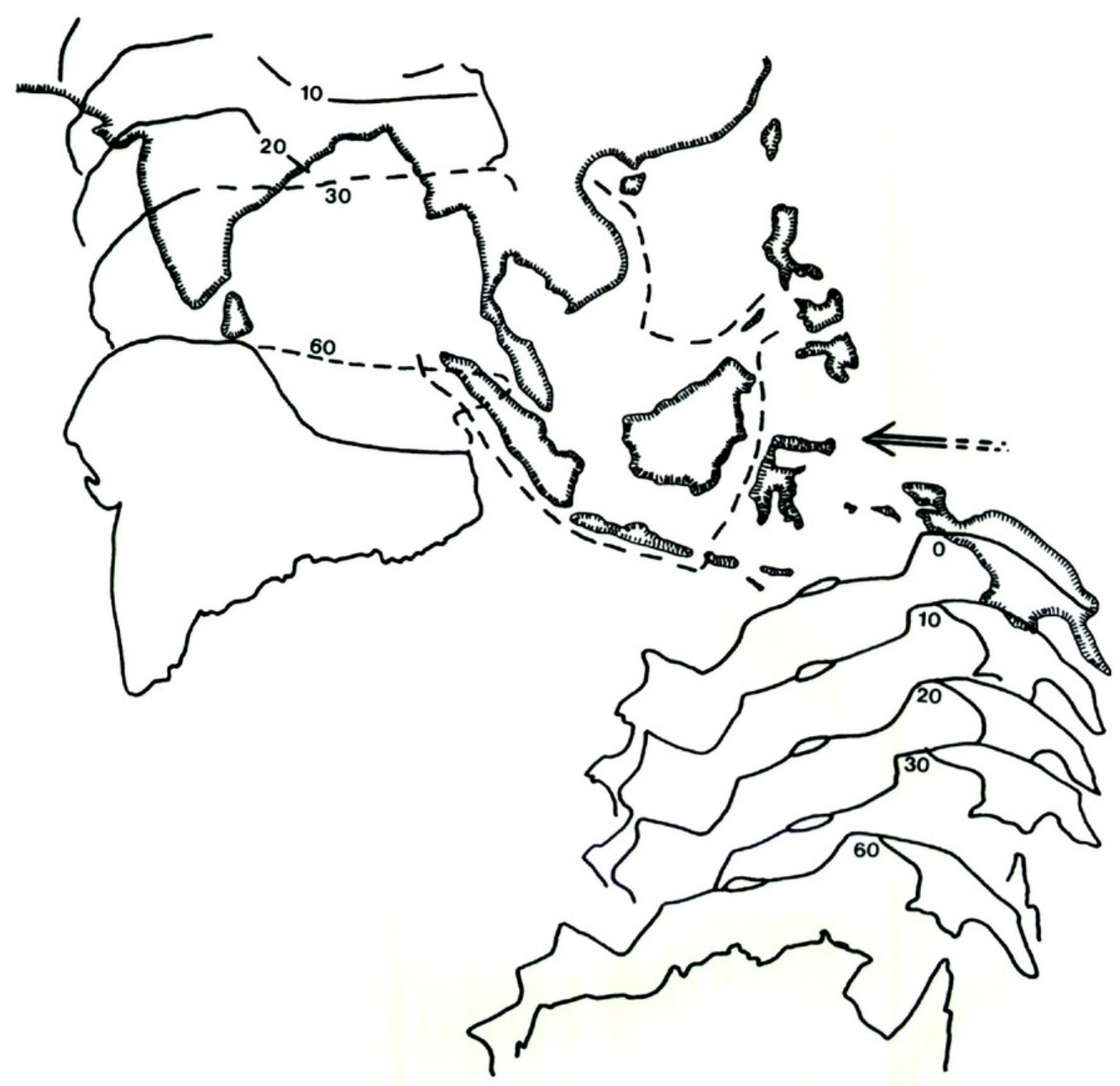

Figure 3. The position of Australia in relation to Southeast Asia. The position of the Australian and Indian Plates for present and 10, 20, 30, and 60 million years ago are shown. In the early Tertiary there was $3,000 \mathrm{~km}$ of deep ocean between the Australian and Southeast Asian Plates. The two came into contact 15 million years ago, in the Miocene. Modified from Powell and Johnson, 1980.

arctica, this current could not operate and the warm equatorial currents travelled to higher latitudes along the eastern margins of the southern continents, effecting a greater heat transfer from the low to the high latitudes. Once the circumpolar current came into operation, it effectively blocked the equatorial currents from travelling into the higher latitudes, thus limiting the heat transfer to these regions.

During the initial drift of Australia away from Antarctica the seas between the two land masses were shallow and the circum-Antarctic current was blocked by the South Tasman Rise, which linked Tasmania to Antarctica. To the end of the Eocene, the Southern Ocean was relatively warm and Antarctica largely nonglaciated. In the early Oligocene, substantial sea ice began to form and widespread glaciation developed on Antarctica. The clearing of the South Tasman Rise about mid-Oligocene time and the opening of Drake Passage between South America and Antarctica about the Oligocene-Miocene boundary (Barker \& Burrell, 1977) allowed complete circumpolar circulation. The Antarctic ice cap formed about mid-Miocene time. The volume of ice has increased since this time and was greater than that of the present in the late Miocene (Kennett, 1977; Kemp, 
$\delta^{18} 0$

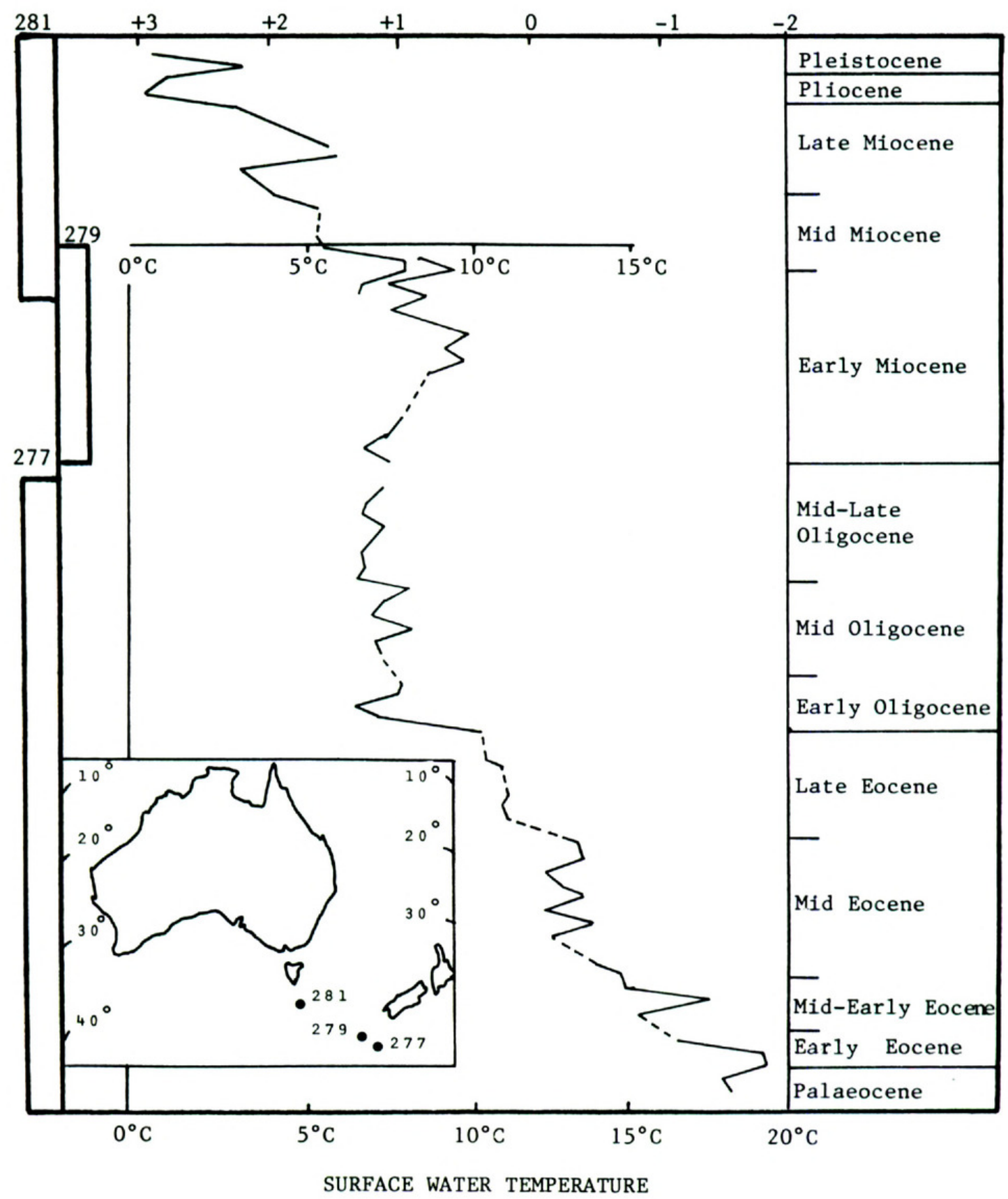

FIgURE 4. Oxygen isotope paleotemperatures, modified from Shackleton and Kennett, 1975. $\delta^{18} \mathrm{O}$ is the correction for the change of the ratio of the isotopes in sea water through the Cenozoic. Note: Sites 277 and 279 on the Campbell Plateau were about $50^{\circ} \mathrm{S}$ in the early Tertiary. The composite curve presented here represents the paleotemperatures of latitudes $40-50^{\circ} \mathrm{S}$, for the whole of the Cenozoic.

1978, 1981). The decline in temperature during the Cenozoic is shown by the oxygen isotope temperature curve from deep sea cores on the Tasman Rise and Campbell Plateau, which have remained at latitudes of $40-50^{\circ} \mathrm{S}$ for the whole of the Tertiary (Fig. 4). There was an overall decline through the Eocene and substantial drops in temperature during the early Oligocene and after the mid-Mio- 


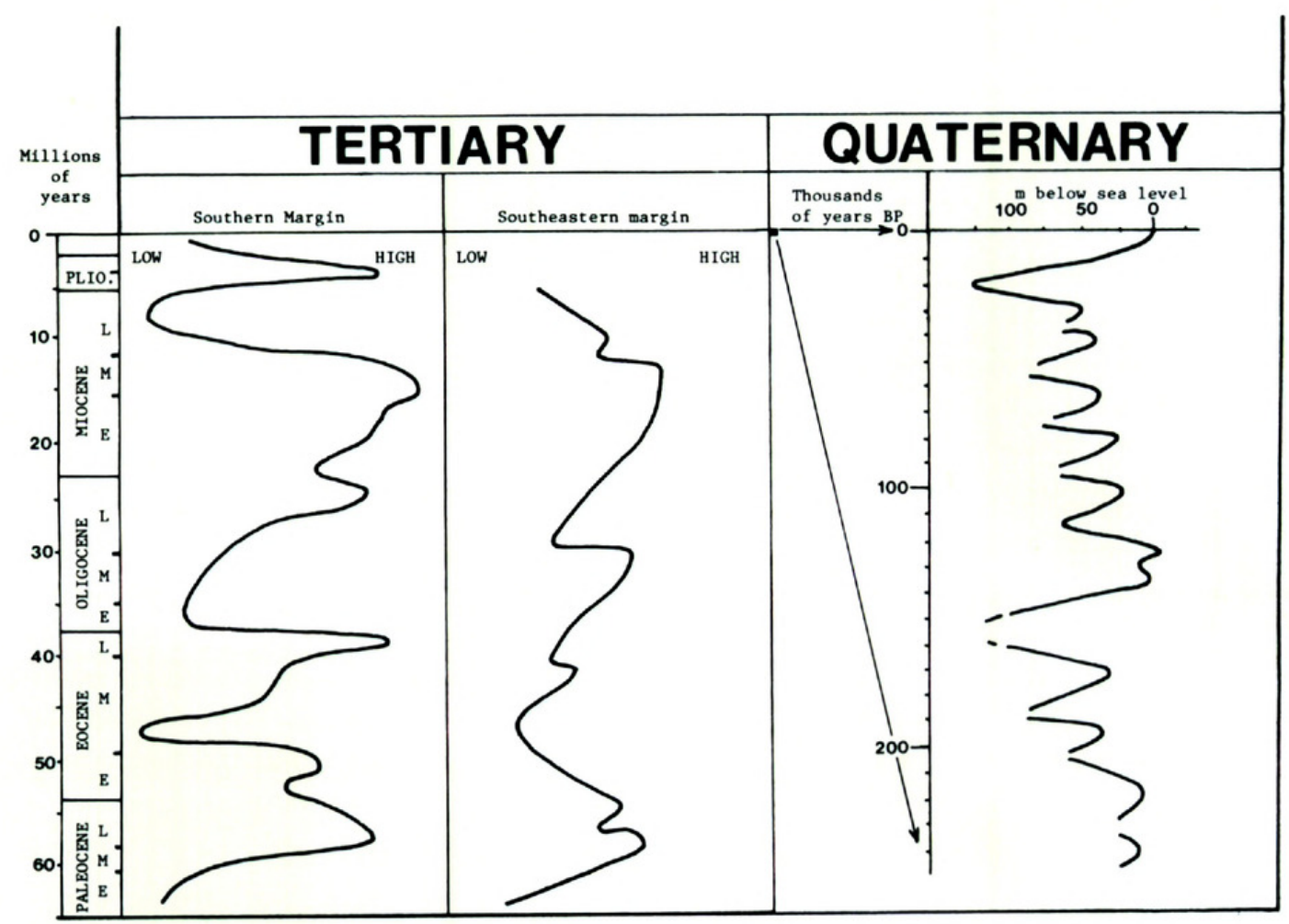

Figure 5. Cenozoic changes in sea level in the Australian region, from the sedimentary cycles of Loutit and Kennett, 1981, and Chappell, 1978. The two Tertiary curves show sedimentary cycles on the continental margins and changes in sea level have been the major factor determining deposition. There is an overall agreement but they are not identical because of slightly different histories of deposition. The Quaternary curve for sea levels is for the last 250,000 years only. For further explanation, see text.

cene (Shackleton \& Kennett, 1975). Throughout the overall decline, there are many fluctuations. That these fluctuations are important, biogeographically, is shown by the foraminiferal record. Tropical foraminifera show a number of shortlived excursions into the higher latitudes, and these excursions show a good fit, on the whole, with the oxygen isotope curve (McGowran, 1978).

Changes in sea levels through the Cenozoic have alternately exposed and drowned the continental shelves. Figure 5 shows two Tertiary sea level curves taken from Australian sedimentary cycles. A third, from the Western Australian continental shelf (Quilty, 1980), is very similar to the southern Australian curve shown on Fig. 5. The two curves show an overall agreement, but are not identical because of the different histories of deposition (Loutit \& Kennett, 1981). These cycles in sea levels can be equated, in a general way, with world wide changes (Vail et al., 1977). It is thought that geotectonics, variations in rates, and directions of sea floor spreading, etc., have been the cause of these changes. The eustatic glacial cycles of the Quaternary are superimposed on the longer term cycles, although there was some glacial influence on sea levels before the Quaternary. At times of high sea levels, shallow flooding of the continental shelves and low lying areas results in a warm, wet climate. At times of low sea level, the low lying areas are drained and the continental shelves exposed, resulting in a climate that is cooler and drier.

The long term changes in sea level through the Cenozoic are measured in 
terms of millions of years while the glacial cycles of the Quaternary can be expressed in terms of thousands of years. Figure 5 shows the sea level changes over the last 250,000 years (Chappell, 1978). This curve has been constructed from coral reefs in New Guinea, Timor, and the Barbados and shows a number of fluctuations between the major interglacial high levels.

Oceanic circulation and the development of the ice cap on Antarctica has had a major influence on Australian paleoclimate. Kemp $(1978,1981)$ used data from deep sea sediments to model atmospheric circulation. There are, however, many indications on the land itself as to the nature of the paleoclimate, although much of it is not as reliably dated as that of the deep sea cores. There is abundant evidence that inland Australia was once much wetter than today. Residual laterite and kaolinized profiles are widespread in Australia, including the arid region. The chemical weathering required to produce these profiles would require a warm, humid climate with a much higher rainfall than that received in inland Australia today. The ages assigned to laterite in the various regions are different, because there has been more than one episode of lateritization (Hayes, 1967; Alley, 1977; Idnurm \& Senior, 1978). Paleomagnetic dating suggests that the dominant period of lateritic weathering over a large area of Australia was late Oligocene to early Miocene (Schmidt et al., 1976). The Cenozoic stratigraphy of the Lake Eyre Basin indicates an alternation of relatively humid and dry periods, but the present degree of aridity did not appear until the Quaternary (Jessup \& Norris, 1971). In the Lake Frome area, the climate of the Miocene was subtropical or warm temperate with a relatively high rainfall and, at times, seasonal dry periods became a part of the weather pattern. Arid and pluvial climates alternated in the late Tertiary and Quaternary (Callen \& Tedford, 1976). River systems in the arid region of Western Australia have been inactive since middle Miocene time and are now reduced to a chain of salt lakes (van der Graaff et al., 1977).

The aridity of the Australian continent reached its present proportions in late Pliocene-Pleistocene time, about 2.5 million years ago (Bowler, 1976). There is some debate as to how the present state of aridity was reached. One school of thought places the first beginnings of a drier climate in the Eocene, using the notion that offshore terrigenous sediments infer river drainage (Quilty, 1974) and that the change from terrigenous to carbonate sedimentation is an indication of the cessation of efficient drainage from the land. (This hypothesis contradicts the paleomagnetic dating of laterites, discussed above, if the possibility of fluctuations in climate is ignored.) Another school of thought interprets the same evidence as indicating drainage from a flat, well-vegetated terrain with a consequent lack of erosion. This second school of thought places the start of desiccation in the late Miocene (Bowler, 1976). There is general agreement, however, that at least localized dry areas have probably existed in inland Australia long before the present state of aridity was reached. If, during the Tertiary, very small pockets of aridity existed amid large areas of better watered country, they may be very difficult to detect by normal geological and paleontological methods. Such small pockets would be biologically very important, for they would allow the evolution of a genetic complement suited to the arid environment, forming a nucleus for later expansion. 
The climatic changes of the Tertiary are described in terms of million of years, but those of the Quaternary may be described in terms of thousands of years. Bowler et al. (1976) have reviewed evidence of the climates of the last 60,000 years. From 25,000 to 15,000 years B.P., which includes the last glacial period, it is estimated that the mean annual temperature was lowered by $6-10^{\circ} \mathrm{C}$. Glaciation was restricted to Tasmania and small areas in the Snowy Mountains, although periglacial activity extended much further in the Eastern Highlands. There is considerable evidence of a drier climate throughout the whole time, although in southern Australia lakes filled at the time that temperatures were lowest, probably as a result of reduced evaporation. In the last 10,000 years, the climate has been relatively stable.

Nix and Kalma (1972) have constructed models of changes that have occurred since the last glaciation. These models (see Fig. 6) include the postulated type of vegetation that would result from the climate prevailing at the time, but they have been built from the climatic controls of the vegetation. These models reflect the major influence of lowered sea levels that accompanied maximum glaciation. With the sea level at the margin of the continental shelf, the continentality of a low land mass such as Australia would be increased considerably. With deeper, colder seas surrounding Australia, evaporation and hence precipitation would be less. Changes similar to these must have happened many times during the Quaternary as the sea level oscillated with the glacials (see Fig. 5). Evidence from soils (Butler, 1967) and hydrologic regimen (Schumm, 1968) indicate alternating phases of unstable erosion/deposition and stable non-erosion/non-deposition during the Quaternary. It is thought that the disturbing effect of an unfavorable climate reduces the vegetation cover and erosion is accelerated. Such cycles of instability and stability of only a few thousand years duration must have had a profound effect on the biota.

\section{THE CLIMATE TODAY}

Aridity is the major feature of the climate of the Australian continent today. More than two thirds of the continent receives a mean annual precipitation of less than $500 \mathrm{~mm}$ and a third has values of less than $250 \mathrm{~mm}$. Precipitation zonation is roughly concentric with the highest values across the northern edge and down the eastern coastal strip. Even the well-watered coastal regions receive a seasonal precipitation so that $80 \%$ of the continent has at least three months of the year without effective precipitation. Roughly the northern half of the continent receives summer precipitation and the southern half winter precipitation. New Guinea and Western Tasmania are the only significant areas of a humid climate receiving more than $2,000 \mathrm{~mm}$ mean annual precipitation.

For biogeographic purposes, the extremes of temperature are perhaps more instructive. All but the highest elevations near the coast of continental Australia receive mean daily maxima exceeding $30^{\circ} \mathrm{C}$ during the hottest part of the year. In the coldest part of the year, freezing temperatures and frosts occur regularly over roughly half the continent. For a more detailed discussion of the climate, see Nix (1981). 

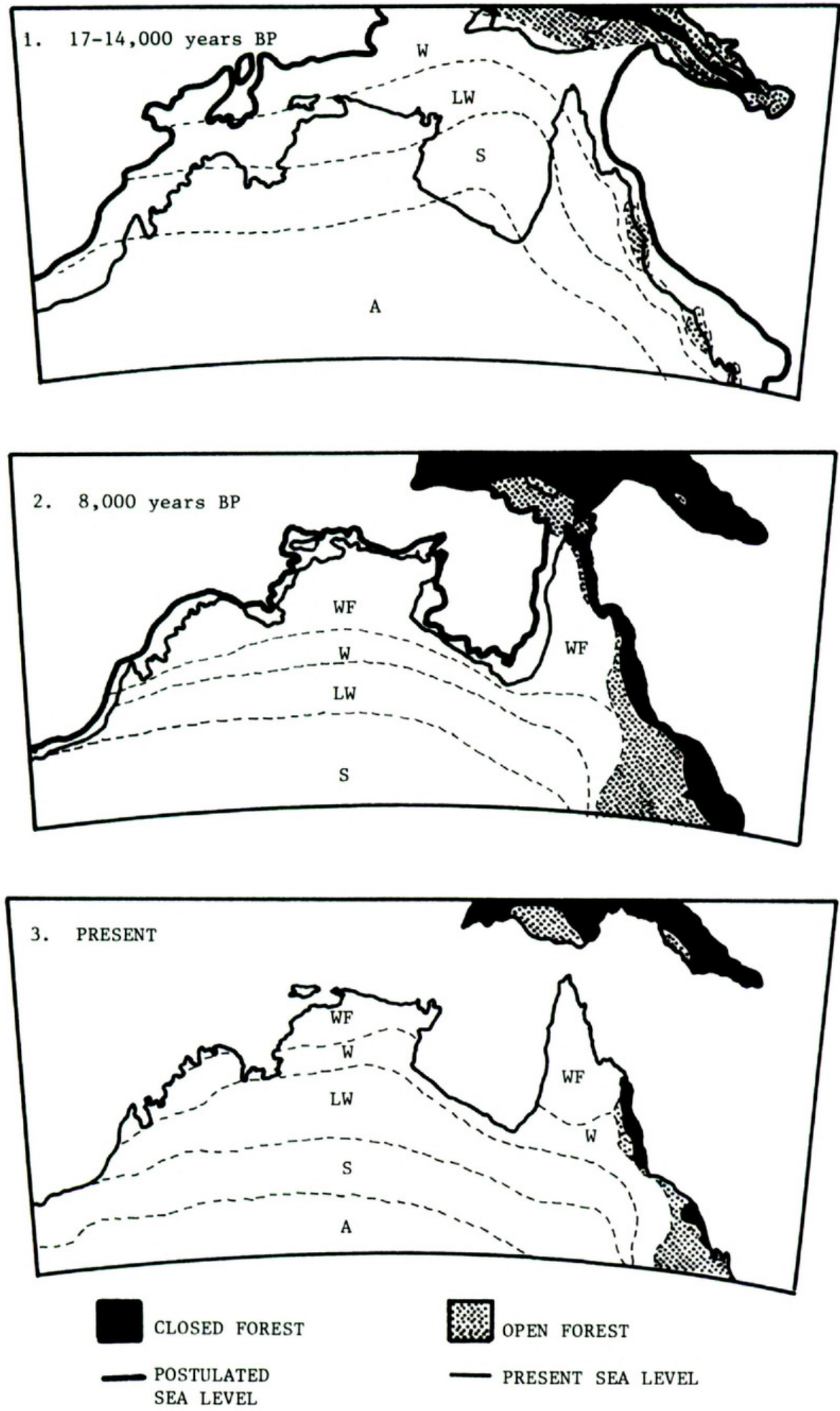

FIGURE 6. The main types of vegetation that might result from the climate postulated for stages since the last glacial period, from Nix and Kalma, 1972. 1. For the period of maximum sea level lowering. The loss of warm shelf water has greatly reduced precipitation and continentality has increased. The arid vegetation would have expanded and the closed forest (= rainforest) contracted, with a corresponding shift of the intermediate types. 2. For the period of rapid rise in sea level and rapid warming of very shallow shelf water, resulting in a greatly increased precipitation. Temperatures are slightly higher than those of today. The closed forest would have expanded considerably and the 


\section{SOILS}

"There is probably no continent with soils so generally low in key plant nutrients as Australia ..." (Bowen, 1981). Soils of high and moderately high nutrient status are restricted to an archipelago of islands on the Australian continent although they are fairly extensive in New Guinea. Soils of low and very low status are widespread and probably cover more than half the area of the continent. Gross deficiencies exist in both major and minor nutrient elements (Nix, 1981).

The low nutrient status of the soils is attributed partly to the mainly sedimentary parent material, and mostly to the prolonged deep weathering of the landscape and the stripping and reworking of older soil profiles (Nix, 1981). Since the present low status results from the once wetter climate and resultant processes of lateritization that were in progress during the early Tertiary, then the soils must have had a low nutrient status all through the Cenozoic.

There is some evidence of change in nutrient status of the soils during the Cenozoic. Volcanism has provided restricted areas of new parent material and has produced the islands of higher nutrient soils. In a second example, numerous water bores in western New South Wales have revealed two formations in the Cenozoic alluvium. The older, underlying formation contains sands and gravels that are almost entirely quartz and it is predominantly grey in color. The younger, overlying formation is varicolored, frequently red-yellow-brown and the sands and gravels are an admixture of the various rock types exposed in the catchment today. It is thought that the quartz in the underlying formation came from extensive quartz gravels that once blanketed the region but have now been eroded away except for remnant hill-cappings (Williamson, 1964). However, the transition between the two formations is time transgressive; about mid-Miocene in the western region on the riverine plain and late Pliocene-early Pleistocene in the eastern region in the river valleys. The pollen assemblages of the two formations always indicate a wetter climate for the lower and a drier climate for the upper formation (Martin, 1973, 1977a). This evidence suggests that there is at least a climatic component in the development of the two formations. Although there are no direct measurements, soils formed on predominantly quartz, under a wetter climate, are likely to have had a lower nutrient status than those of today that are formed on a variety of rock types with less weathering. Thus the little evidence available suggests that during the Tertiary, some soils were even less fertile than those of today.

\section{The Vegetation Today}

So that past changes in the environment and the vegetation may be fully appreciated, a brief outline of the phytogeography and the factors controlling the

arid vegetation would be much reduced. 3. Present day, with deeper, cooler shelf water and the cooling effects of the current through Torres Strait. Temperatures and precipitation are slightly lower. There is a slight retreat of closed forest and an expansion of the arid vegetation. W, woodland. LW, low open woodland. WF, woodland/open forest. S, shrubland. A, arid vegetation. 


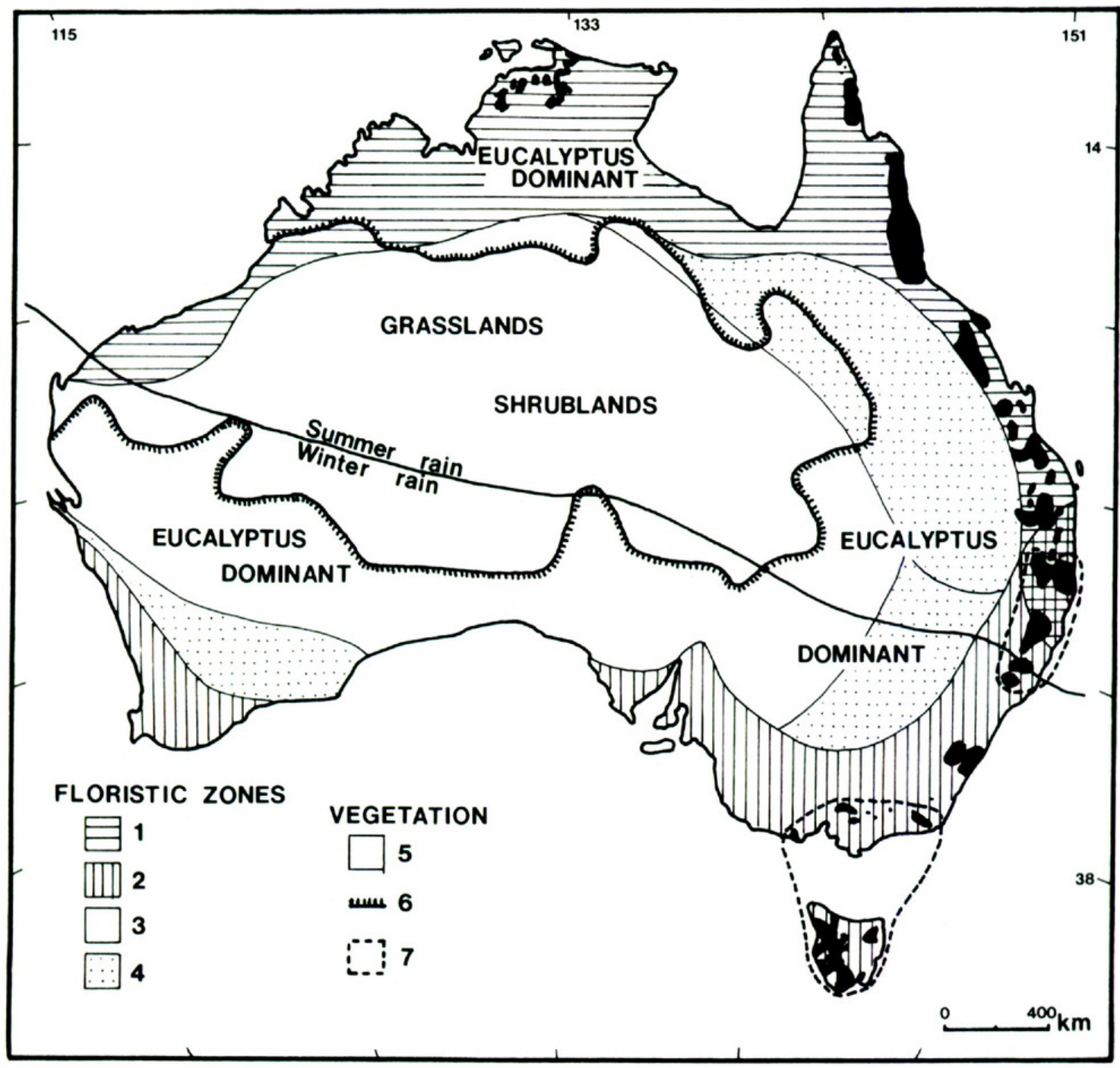

FIgURE 7. The floristic zones (from Burbidge, 1960) and major categories of vegetation (simplified from Specht, 1970 and Webb \& Tracey, 1981b). 1. Tropical zone. 2. Temperate zone. 3. Eremaean zone. 4. Interzone areas. 5. Closed forests (= rainforest). 6. The boundary between Eucalyptus dominated communities and those with a mixture of dominants. 7. Areas where Nothofagus may be found in the closed forests. For further explanation, see text.

vegetation today are presented. Figure 7 shows the three main floristic zones recognized by Burbidge (1960), the discontinuous distribution of rainforest, and the approximate limits of the dominance of Eucalyptus. In most of the Eremaean Zone, Eucalyptus is present but not dominant. Acacia is one of a mixture of dominants here, but it is also very common in the understory where Eucalyptus is dominant.

There are small areas of rainforest (= closed forest) along the northern and eastern coast (see Fig. 7). Although the rainforests are located in areas dominated by Eucalyptus, the latter is not a normal constituent of mature rainforests and there are few floristic affinities between adjacent rainforest and eucalypt communities. Tree species of mature rainforest must be able to regenerate under a well-developed or only slightly disturbed canopy. The rainforests are monsoonal and tropical in the north, subtropical and warm temperate along the east coast, 
and cool temperate in the southern limits of their range. Tall closed forests require about $1,500 \mathrm{~mm}$ of precipitation per annum for extensive development (Francis, 1951), although rainforest elements growing as low forest with emergent Araucaria may receive only $900 \mathrm{~mm}$ p.a. (see Webb, 1978). Small pockets of rainforest may be found outside of the general climatic limits where the available moisture is supplemented, e.g. by seepage, mountain fog, or soils of higher fertility, especially in fire shadows that are protected from wild fires. These pockets may be only a few hectares in area, too small to be mapped, but biologically they are very important. In areas that are climatically favorable, the most complex rainforest is restricted to the soils of higher nutrient status or niches favorable for nutrient accumulation. Provided rainfall is high, soils of lower nutrient status may support simple evergreen types of rainforest that are typically mixed with sclerophylls. Eucalyptus and sclerophylls are dominant on the lower nutrient soils, which do not support rainforest especially where exposed to wildfires. Nothofagus, which is so conspicuous in the paleobotanical record (discussed below), is restricted to the areas shown on Fig. 7 where it is one of the few taxa of trees in mature temperate rainforest (Webb \& Tracey, 1981a, 1981b; Howard, 1981). Eucalyptus requires light for germination and, even under a disturbed canopy, usually requires exposure of mineral soil for establishment.

The region dominated by Eucalyptus may be divided into (1) tall open forest, (2) open forest, (3) woodland, and (4) scrubs and shrublands. These divisions broadly follow the rainfall gradient with the tall open forests in the wettest and the scrubs and shrublands in the driest regions.

In tall open forests (or wet sclerophyll), the eucalypts are from $40 \mathrm{~m}$ to 100 $\mathrm{m}$ in height and there is a shrub layer of mesic taxa. In many places, eucalypts are emergent above well-developed rainforest. Such forests are clearly successional and are potentially capable of developing into rainforest. Tall open forests are found in the higher rainfall areas or the more protected sites. Because Eucalyptus requires light for germination and rarely regenerates under a closed canopy, fire regenerates and shapes the development of these forests. If fire is too frequent, i.e. before the eucalypts reach flowering age, it will eliminate $\mathbf{E u}$ calyptus. Fire also prevents the succession proceeding towards rainforest (Ashton, 1981).

The eucalypts in open forests (or dry sclerophyll) are quite variable in height but less than $30 \mathrm{~m}$. Moisture relationships appear to be the most important factor for tree growth and density. The hard-leaved shrubby layer, so distinctive of the dry sclerophyll forests is found on the more infertile soils, whereas the understory is grassy on soils of a better nutrient status (Gill, 1981). Efficient nutrient cycling is important on the infertile soils. Nitrogen fixation, mycorrhiza, and proteoid roots enhance the mineral status of the sclerophyllous communities (Bowen, 1981). At least one species of Eucalyptus utilizes insoluble phosphate (Mullette et al., 1974). Added fertilizers may increase growth of sclerophyllous shrubs, but then the shrubs may also become more drought susceptible (Specht, 1963). The slower growth rate imposed by low soil fertility may confer drought resistance (Parsons, 1968). In general, any means of increased drought resistance involves a cost to the plant in a reduced growth rate (Cowan, 1981). Thus the mechanisms of coping with low nutrient status and water stress may not be independent.

Grassy woodlands (savannah woodlands) characterized by well-spaced trees 
are generally found on the better soils. Almost all of the woody taxa belong to either Eucalyptus or Acacia (Gillison \& Walker, 1981).

Scrubs and shrublands (or mallee) are dominated by Eucalyptus with many stems arising from an underground lignotuber (mallee growth habit). Some species of Eucalyptus may grow both as a tree or a mallee, depending on growing conditions. The dominants are $2 \mathrm{~m}$ to $8 \mathrm{~m}$ in height. Acacia is also common here. The understory consists of sclerophyllous shrubs on the infertile soils, sparse grasses on the more fertile soils and chenopodiaceous shrubs in the drier regions (Parsons, 1981).

Shrublands and grasslands are the major vegetation types in the Eremaean Zone. Species of Eucalyptus are present but not usually dominant. Shrublands may have both large and small shrubs. The abundant large shrubs include Acacia and, less frequently, the mallee form of Eucalyptus (Johnson \& Burrows, 1981). Chenopodiaceous shrubs are common in the southern part of this zone (Leigh, 1981). Tussock (Astrebla) and hummock (Triodia and Plectrachne) grasslands are found in the northern part of the arid region (Groves \& Williams, 1981). Throughout, the low and erratic rainfall is the controlling factor. Nutrient status is generally low because the soils have been formed on the highly weathered and leached parent material. However, the most important soil characteristics are those that control the amount and availability of water (Perry \& Lazarides, 1962).

\section{The Paleobotanical Record}

Reconstructions of the flora and vegetation presented here come mainly from pollen studies. Work is in progress on macrofossils and provides much valuable evidence but it is not yet sufficient to be used for the reconstructions that are possible from pollen. When relying on evidence from pollen, it is important to bear in mind that there is a bias. When pollen and leaves have been identified from the same deposit, the two assemblages may contain quite different taxa. For example, mid-Eocene deposits contain pollen of Nothofagus and Myrtaceae but no leaves of these taxa (Christophel, 1981a). The reason for this difference is that leaves are derived mainly from the margins of the site of deposition of clastic sediments so that stream-side taxa are overrepresented. In coals and peats, however, leaves are produced on site. Most leaves do not transport well. On the other hand, pollen in a sediment is derived from a much greater area, probably the whole of the catchment of the depositional basin although most of it is produced locally. The heavy pollen producers, which are wind pollinated, are usually overrepresented in the assemblage. Water-transported pollen may constitute a significant fraction (Birks \& Birks, 1980, p. 179). Additionally, some leaves do not preserve well, e.g. Quintinia, which is highly underrepresented in the leaf litter although it is relatively common along streams (Christophel, pers. comm.). Some pollen does not preserve, e.g. the Lauraceae, an important family in some parts of Australia. These differences result in apparent discrepancies between the interpretations from macrofossil and from palynological evidence. However, these two lines of evidence are complementary, not in competition, and when they can be integrated into one paleobotanical interpretation a more balanced and complete story will emerge.

Another important bias results from the conditions necessary for the preser- 
vation of plant remains, viz., the anaerobic swamps, bogs, lake bottoms. Such requisites are abundant in high rainfall areas but exceptional under a dry climate or a strong seasonal drought. Consequently, the paleobotanical record is largely that of the wetter climates.

The level of identification in the fossil record is quite variable, particularly for pollen. Fossil populations are easily identified, but they rarely coincide with extant populations. Thus the fossil type may be found in several related genera but not necessarily in all species. Frequently, identifications can be made only to the family or a higher level.

A reliable age for the fossils is essential, but dating is frequently a problem. Many of the fossiliferous deposits are isolated and thin, and palynology is often the only means available for dating such deposits, with consequent dangers of a circular argument. The ages of some deposits are still being debated.

\section{TAXA IDENTIFIED IN THE AUSTRALIAN TERTIARY}

The list below includes pollen and macrofossils. The older macrofossil work which based identifications on gross morphology only is considered as unreliable and not included here. For references to the older work, see Duigan, 1950. Cookson and her co-workers consistently used epidermal and other cellular detail as confirmation of identifications. Their work and that of subsequent authors is included here. Botanical names are preferred and the reader is referred to the reference for fossil names and the proof of identification. Taxa listed without a reference have been reviewed in Martin (1978) and this reference is not repeated. Where a taxon has not been reviewed in Martin, 1978, and the fossil name is necessary to follow the literature, then it is included here in brackets. Throughout the rest of the text, fossil names are only used where necessary for clarification. Where there have been taxonomic revisions, only the latest reference is given. Where the identification and Australian occurrence are found in separate references, both are given. The qualifications and suffixes are those used by the original authors, viz.

Type-a good fit with reference material but it may not be restricted to the particular taxon

Comp-compares favorably with existing reference material

Sim-a strong similarity between fossil type and the present day taxon

Like-strong evidence for the identification

No suffix - a reasonably certain identification.

Type of fossil indicated thus:

$\mathrm{P}$-pollen

L-leaves or leafy shoots

$\mathrm{C}$ - cones or cone scales of gymnosperms

$\mathrm{K}$-flowers

$\mathrm{F}$-fruits of angiosperms

$\mathrm{S}$-seeds

W-wood. 


\section{GYMNOSPERMAE}

Zamiaceae: Bowenia L Hill, 1978; Lepidozamia L Hill, 1980.

TAXodiaceae: Athrotaxis L Townrow, 1965b.

CuPRESSACEAE: Cupressaceae P not identified further; Callitris sp. L Blackburn, 1981b; three forms related to Papuacedrus L Offler, 1969.

Podocarpaceae: Phyllocladus P \& L Cookson \& Pike, 1954, ? W Patton, 1958; Dacrydium type 1, D. franklinii P; Dacrydium type 2, Section B of the genus P, L \& S Cookson \& Pike, 1953b; three forms of Dacrydium related to sections A, B and C respectively L Offler, 1969; Podocarpus type 1, section Dacrycarpus P \& L Cookson \& Pike, 1953a, Townrow, 1965a; Podocarpus type 1, most other sections in the genus, P \& L Townrow, 1965a, L Blackburn, 1981a, at least 5 spp. Blackburn, 1981b; Microcachrys P; Microstrobos L Townrow, 1965a.

Araucariaceae: Araucariaceae P not distinguishable to generic level; Araucaria L \& C Cookson \& Duigan, 1951; Agathis L \& C Cookson \& Duigan, 1951, W Patton, 1958.

\section{Angiospermae Subdivision Dicotyledonae}

WINTERACEAE: Tasmannia $(=$ Drimys $)$ P

MORACEAE: Moraceae comp P Luly et al., 1980.

FagaceaE: Nothofagus, the menziesii pollen type P; Nothofagus, the fusca pollen type P; Nothofagus, the brassii pollen type $\mathrm{P}$.

Casuarinaceae: Casuarina P \& F Pike, 1953, W Patton, 1958. Both Cryptostomae and Gymnostomae L \& F Christophel, 1980, Blackburn, 1981b.

GyrostemonaceaE: Gyrostemonaceae P Luly et al., 1980.

Portulacaceae: Montia P.

Chenopodiaceae/Amaranthaceae: P of Chenopodiaceae and some Amaranthaceae are indistinguishable.

Polygonaceae: Polygonum pantoporate pollen type (Martin, unpubl.).

Elaeocarpaceae: Elaeocarpaceae F Blackburn, 1981b; Elaeocarpus $\mathrm{P}$ Luly et al., 1980.

BomBACACEAE: Bombacaceae (Bombacacidites bombaxoides) P Couper, 1960, Stover \& Partridge, 1973.

Malvaceae: Malvaceae P.

ERICACEAE/EPACRIDACEAE: Ericaceae/Epacridaceae $P$ is very similar.

SAPOTACEAE: Sapotaceae P not identified further.

Evenaceae: Ebenaceae aff. Diospyros K \& L Christophel, $1981 \mathrm{lb}$.

Symplocaceae: Symplocos P.

EUCRYPHIACEAE/CUNONIACEAE (dicolpate): Geissois-Eucryphia comp P Luly et al., 1980; Ceratopetalum comp $\mathrm{P}$ Luly et al., 1980.

CunONIACEAE (tricolporate): Cunoniaceae $\mathrm{P}$ Luly et al., 1980.

Escalloniaceae: Polyosma sim P Luly et al., 1980; Quintinia P.

Mimosaceae: Acacia P \& L Cookson, 1954.

Leguminosae (= Papilionaceae): Leguminosae $\mathrm{P}$ Luly et al., 1980.

Haloragaceae: Haloragis P; Myriophyllum P.

GUNNERACEAE: Gunnera P.

MYRTACEAE: Seven pollen types not reliably identifiable further, Acmena comp Luly et al., 1980; Baeckea comp Luly et al., 1980; Rhodamnia comp Luly et al., 1980; Syzygium-Cleistocalyx comp Luly et al., 1980; Eucalyptus-like F Lange, 1978a; Leptospermum-like F Lange, 1978a; Calothamnus-like F Lange, 1978a; F like Melaleuca-Callistemon Lange, 1978a; Angophora-like F Lange, 1978a.

OnAGRACEAE: Jussiaea (Corsinipollenites) P Traverse, 1955, Hekel, 1972; Fuchsia P, A. D.Partridge, pers. comm., D.Hos, pers. comm.

Proteaceae: Adenanthos-type P. TRIBE BANkSIEAE P\&L Cookson \& Duigan, 1950, L Blackburn, 1981a, 6 spp. of L Blackburn, 1981b; Banksia P Luly et al., 1980, F Cookson \& Duigan, 1950, Pike, 1953, W Patton, 1958; Beauprea P TRIBE GREVILlEAE L Blackburn, 1981a; Grevillea-type P; Helicia-type P; Isopogon-type P; Orites comp P Luly et al., 1980; Xylomelum-type P; Xylomelum comp P Luly et al., 1980; Proteaceae comp P Luly et al., 1980. Many pollen forms attributed to the family have not been identified further. $\mathrm{cf}$. Proteaceae I, II, III and IV L Lange, 1978b.

RHIZOPHORACEAE: Rhizophoraceae (Zonocostites ramonae) P Germeraad et al., 1968, Hekel, 1972. AlangiaceAE: Alangium (Alangiopollis) P Traverse, 1955, Hekel, 1972.

Olacaceae: Anacolosa P.

SANTALACEAE: Santalum P.

Loranthaceae: Amylotheca P; Decaisnina-type P; Loranthaceae $\quad$ P Luly et al., 1980.

Aquifoliaceae: Ilex P. 
EuphorbiaceaE: Austrobuxus-Dissiliaria, the spiny type P; Austrobuxus-Dissiliaria, the non-spiny type P; Choriceras comp (non-spiny) P Luly et al., 1980; Austrobuxus (= Longetia) (spiny) P Luly et al., 1980; Coelebogyne P; Macaranga-Mallotus P; Micrantheum-Neoroepera P; Omalanthus comp P Luly et al., 1980; Petalostigma P; Euphorbiaceae P Luly et al., 1980.

RhAMNACEAE: Rhamnaceae P Luly et al., 1980.

Vitaceae: Vitaceae P Luly et al., 1980.

SaPINDaCeaE: Tribe Cupaniae P; Diplopeltis P; Dodonaea P; Dodonaea cf. D. triquetra P, Martin unpub.

Rutaceae: Melicope comp P Luly et al., 1980; Rutaceae P Luly et al., 1980.

Geraniaceae: Geranium P; Pelargonium P.

Polygalaceae: Polygalaceae P.

AraliaceAE: Araliaceae P Luly et al., 1980; between Fatsia and Harmsiopanax L Blackburn, 1981a.

Gentianaceae: Gentiana sim P Luly et al., 1980.

OleaceaE: Oleaceae P \& L Cookson, 1947; Jasminum comp P Luly et al., 1980.

RuBIACEAE: 'Randia' chartacea type P.

Compositae: Compositae P.

Angiospermae Subdivision MonocotyledonaE

RESTIONACEAE: Hypolaena-type (with centrolepidoid pore) P; Restio-type (with graminoid pore) P; Restionaceae/Centrolepidaceae P Luly et al., 1980

CyPERACEAE: Cyperaceae $P$ not identified further.

GramineaE: Gramineae $P$ not identified further.

SParganiaceae: Sparganium P; Sparganium-type 2 P.

PalmaE: Nypa (Spinozonocolpites prominatus $=$ S. echinatus) P Muller, 1968, Stover \& Evans, 1973, Hekel, 1972.

LiliaceAE: Rhipogonum comp P Luly et al., 1980; Liliaceae comp P Luly et al., 1980.

\section{FIRST APPEARANCES, SOUTHEASTERN AUSTRALIA}

The first appearance and approximate time range of the Tertiary taxa are shown in Fig. 8. Some gymnosperms extend from the middle Mesozoic through the Tertiary. The first angiosperm that can be reliably identified with a modern taxon is Ilex (Martin, 1977b). Other angiosperms that first appear in the late Cretaceous are Nothofagus and the proteaceous type. The Myrtaceae, perhaps the most important family in Australia today, is first seen in the Paleocene. Taxa appear almost continuously through the Tertiary. In the late Tertiary, there are more herbaceous taxa making their first appearance. It is not known whether the first appearances are the result of evolution or migration (probably a mixture of both).

\section{QUANTITATIVE ASPECTS, SOUTHEASTERN AUSTRALIA}

The quantitative aspects through the Tertiary of the major pollen types grouped according to their taxonomic affinities are shown in Fig. 9. As well as the abundant pollen types, there are many other types only found in low frequencies and not shown in Fig. 9. A detailed interpretation and the methods involved are discussed in Martin, 1978. The main points are summarized here:

Paleocene. The gymnosperm group, consisting of ten different pollen types is most abundant in the oldest of the assemblages. The proteaceous group, which may consist of up to 23 different pollen types, is also abundant. Many of these proteaceous types become extinct during the Tertiary. Myrtaceae is present but not abundant. Nothofagus is present only in low frequencies. Judging from the present day pollen dispersal behavior of Nothofagus (Martin, 1978), these low 


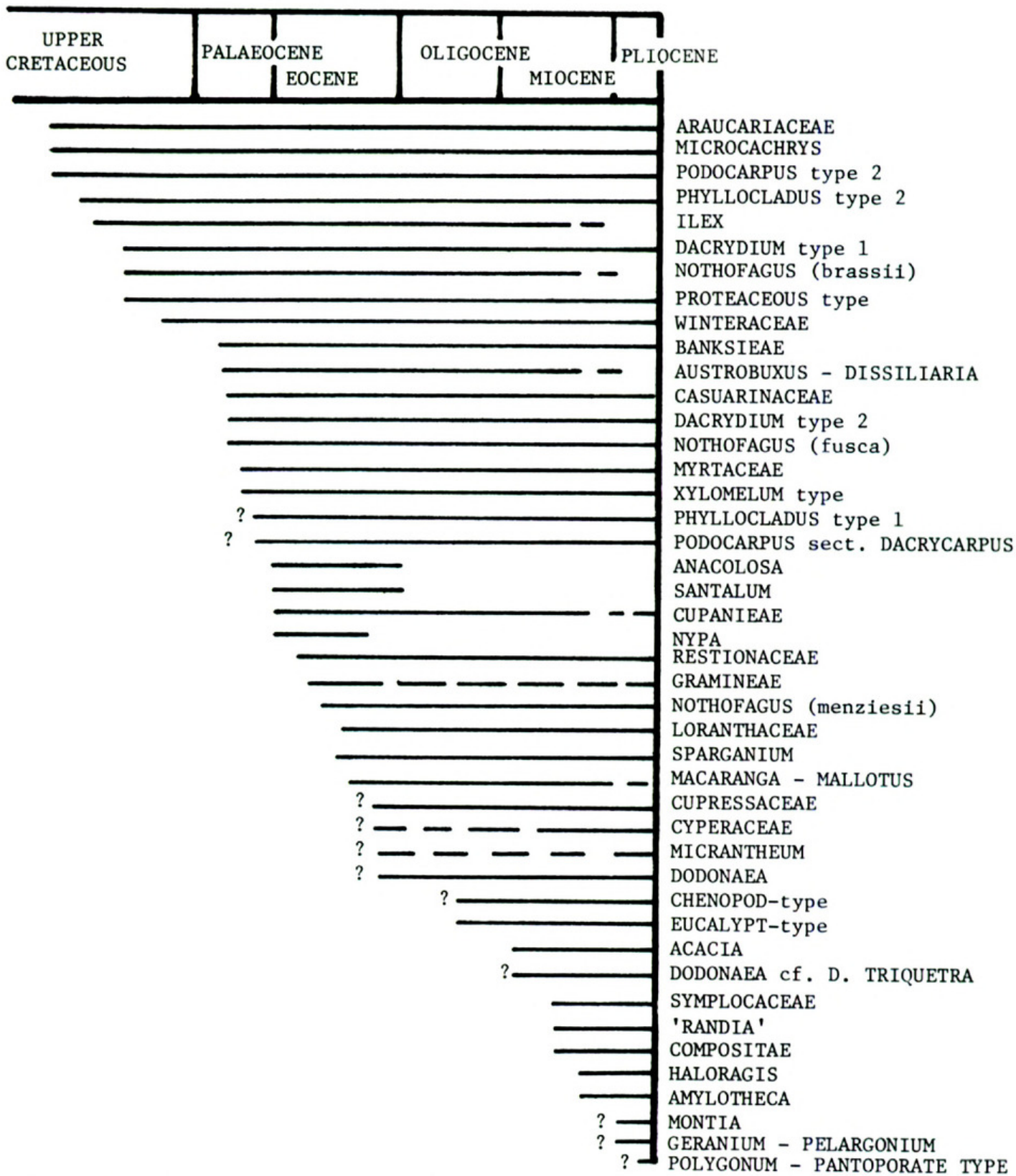

Figure 8. Range chart showing the first appearances of fossil pollen taxa through the Tertiary, for southeastern Australia. Modified from Stover and Partridge, 1973, and Martin, 1978.

frequencies probably indicate that it was not very common and growing at some distance from the areas of deposition. Angiosperms other than these major groups continue to diversify.

Eocene. The early Eocene assemblages are generally like those of the Paleocene, there is a marked change about mid-Eocene time when Nothofagus becomes the dominant pollen group. This great increase in Nothofagus must represent an increase in this taxon in the vegetation, but not to the extent suggested by the pollen frequencies, because Nothofagus is a very heavy pollen producer. Many of the proteaceous types and some other angiosperms became extinct during the mid-late Eocene. 


\section{COWRA-FORBES}
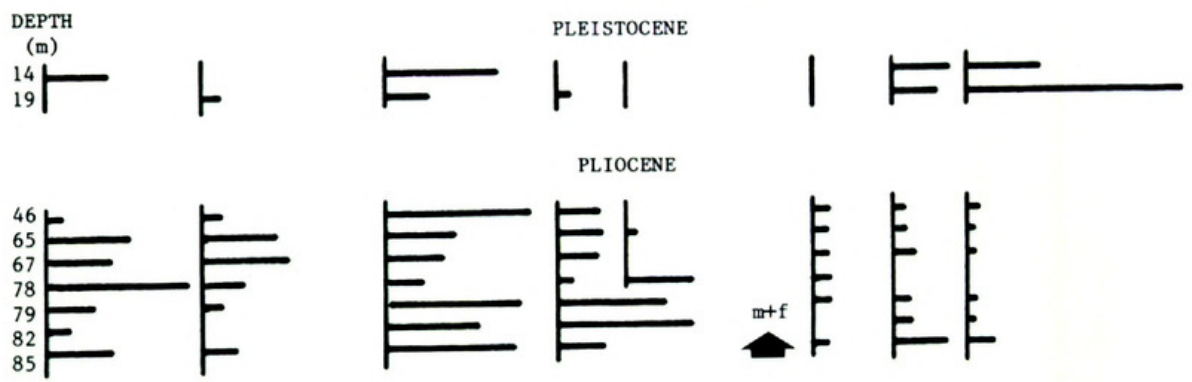

PLIOCENE

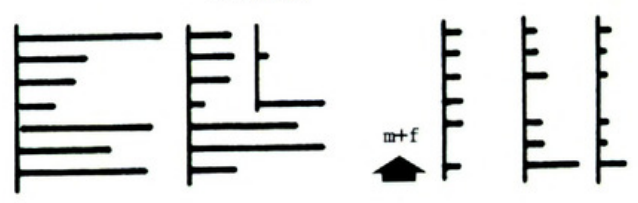

2 MURRAY BASIN - NARRANDERA

LATE MIOCENE

$$
{ }^{9} \vdash \quad \vdash
$$
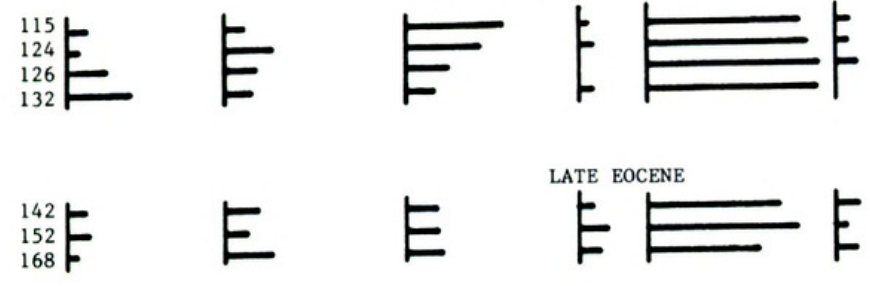

3 MURRAY BASIN - HAY

MID-LATE EOCENE
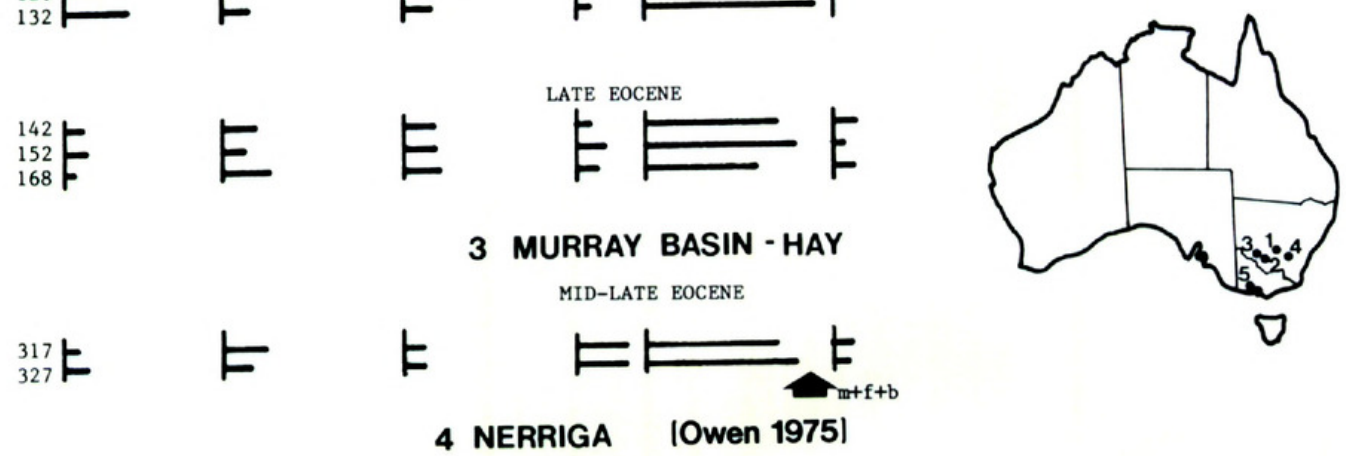

4 NERRIGA IOwen 1975|

EARLY-MID EOCENE

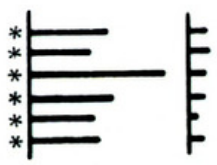<smiles>FC(F)(F)F</smiles>

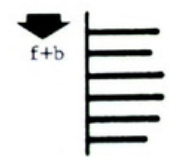

* OUTCROP SAMPLE

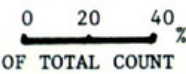

5 OTWAY BASIN - PRINCETOWN (Harris 1965al

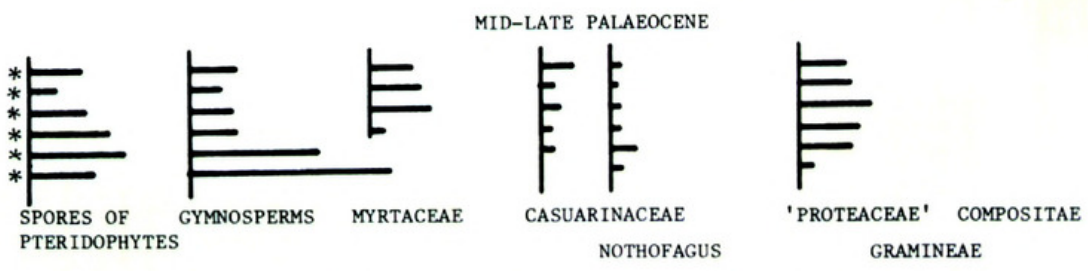

FIGURE 9. General quantitative relationships of the pollen floras through the Tertiary. Only the abundant pollen types are shown, grouped according to their taxonomic affinities. The three types of Nothofagus are shown thus: m, menziesii $\mathrm{f}$, fusca $\mathrm{b}$, brassii.

Oligocene. The pollen floras are dominated by Nothofagus with most other types present in low frequencies. The abundance and diversity of the proteaceous group is lower.

Miocene. The early part of the Miocene is quantitatively similar to the Oligocene. About mid-Miocene time, the abundance of Nothofagus decreases and the Myrtaceae group becomes the dominant. The precise timing of this change is 
earlier inland and later near the southeast coast. There are 8 different pollen types in the Myrtaceae group, but these cannot be identified reliably with extant genera in the family. The 'eucalypt pollen type,' which may be found in other genera besides Eucalyptus, is present but not abundant. The greater proportion of the Myrtaceae pollen is more like that found in Tristania, Backhousia, Baeckea, Syzigium, and Acmena (and possibly other genera). Molds and casts of fruits that are like Eucalyptus, Leptospermum, Calothamnus, Melaleuca-Callistemon, and Angophora (Lange, 1978a) show these genera exist in the fossil record, but they can only be dated as Eocene-Oligocene or Miocene (Ambrose et al., 1979).

Pliocene. Myrtaceae is dominant, although there are small amounts of Nothofagus and a few of the early Tertiary pollen forms are still present. Gramineae and Compositae are usually present but in low frequencies.

Pleistocene. Nothofagus and most of the gymnosperms have disappeared from most of the Australian continent. Myrtaceae continues as the dominant and abundance of Gramineae and Compositae have increased greatly. For further detail of the Quaternary, see Kershaw, 1981.

As well as these abundant groups, there are many pollen types found only in low frequencies (about $5 \%$ or less). These types probably come from plants with a low pollen production and insect pollination, e.g. Acacia, which is important in the vegetation today. Thus a consistent presence of a low frequency taxon is thought to indicate that it may have been important in the vegetation. Many of these low frequency taxa show changes about the time of change in the dominant groups.

These quantitative relationships must represent vegetation that was closed forest through most of the Tertiary, judging from the low herbaceous content (Gramineae and Compositae). A physiognomic analysis of some Eocene leaf floras of southeastern Australia shows them to be most similar to Simple Mesophyll Vine Forest, Complex Notophyll Vine Forest, and Simple Notophyll Vine Forest. These forest types are found today in the rainforest along the east coast of Australia between the latitudes of $15^{\circ} \mathrm{S}-25^{\circ} \mathrm{S}, 20^{\circ} \mathrm{S}-35^{\circ} \mathrm{S}$ and $15^{\circ} \mathrm{S}-37^{\circ} \mathrm{S}$ (at higher altitudes), respectively (Christophel, 1981a). The modern rainforests are classified into these physiognomic types on the size of mature, exposed, 'sun' leaves from the tree layers only (Webb, 1959). Fossil leaf floras would contain some of the larger 'shade' leaves, which would inflate the perception of tropicality/subtropicality. However, the diversity of angiosperms represented suggests a complexity now found only under warmer conditions, and certainly not in temperate forests (Webb et al., 1982). If the Eocene pollen and leaf floras are compared, then the latter indicate a much greater diversity in the flora (Christophel, 1981b), but this may be a reflection of the regional versus local representation, respectively, of the two types of fossils.

The nature of these closed forests change through the Tertiary, but it is not until the Pliocene that the forest started opening up to allow the development of a herbaceous stratum of Gramineae and Compositae, at least in southeastern Australia. Open woodlands and/or grasslands did not develop until the Pleistocene (Martin, 1978) in southeastern Australia although the timing of this major change in the vegetation is earlier in inland regions and in Queensland (discussed more fully below). 


\section{VARIATION IN THE TERTIARY FLORAS}

The general quantitative relationships of the Tertiary floras shown in Fig. 9 are usually recognizable in pollen assemblages of the same age. However, this does not imply that the vegetation was more uniform than that of today. Attempts to identify pollen assemblages from surface samples of moss polsters, surface lake muds, etc., with the parent vegetation have shown that they are identifiable at the "vegetation-landform unit" level, i.e. large vegetation units. When individual plant associations are sampled, little distinction could be made below the level of vegetation-landform unit (Birks \& Birks, 1980, p. 243). Consequently, these Tertiary pollen assemblages shown in Fig. 9 should be viewed in the light of large vegetation units. However, with the use of improved methods, more precision in identifying plant communities in the fossil assemblages is possible (see Luly et al., 1980). Even so, when sufficient samples of the same age are compared, they reveal some time-related and geographic variation in the Tertiary floras, although the problems of dating (discussed previously) should be remembered.

Mid-late Eocene Comparisons. Figure 10 compares four mid- and late Eocene assemblages. Three sites are late Eocene, one (St. Vincent's Basin) is mid-Eocene. Figure 10 shows that the spores of pteridophytes are less frequent in inland locations. Trapping of modern pollen has shown that fern spores form a greater proportion of the catch from water transport than from aerial transport (Birks \& Birks, 1980). Narrow gullies are more favorable habitats for ferns, so there may be other environmental reasons besides climate for these differences. Only Albany would have been coastal-oceanic (or near coastal) on Eocene paleogeography. Casuarinaceae may have been more abundant elsewhere in Australia with up to $62 \%$ in one sample of the Officer Basin. It is not possible to distinguish Gymnostoma from Casuarina on pollen morphology (Kershaw, 1970a). If Casuarinaceae grew in or along the margins of the swamps or lakes, then it could produce a higher pollen representation. Nothofagus may have been more abundant in southeastern Australia, particularly when the Murray Basin is compared to the Officer Basin. The low values in the St. Vincent's Basin are not strictly comparable for these may pre-date the mid-Eocene rise in abundance of Nothofagus. Similarly, the high values of 'Proteaceae' in St. Vincent's Basin may predate the mid-late Eocene decline of this group, but the high values of 'Proteaceae' at Albany are unusual for the late Eocene (Hos, 1975, 1977, 1978; and Martin, 1978).

Variation in Late Eocene to Early Miocene Assemblages Eastern Murray Basin. Numerous bores penetrating strata of this time range have been studied. Figure 11 shows one of the gymnosperms, the Dacrydium franklinii pollen type (= Phyllocladidites mawsonii) plotted as a ratio of the total gymnosperms count alongside the percentage of gymnosperms in the total pollen count. While the percentage of total gymnosperms does not vary much, the relative proportions of the different gymnosperms may change. In the late Eocene-early Oligocene, Dacrydium franklinii is the most common single gymnosperm pollen type in the group. A rise in abundance of $D$. franklinii may be seen in the Gippsland Basin of southeastern Victoria where this pollen type may constitute up to $80 \%$ of the total count in some late Eocene-early Oligocene coals (Stover \& Partridge, 1973). Figure 12 


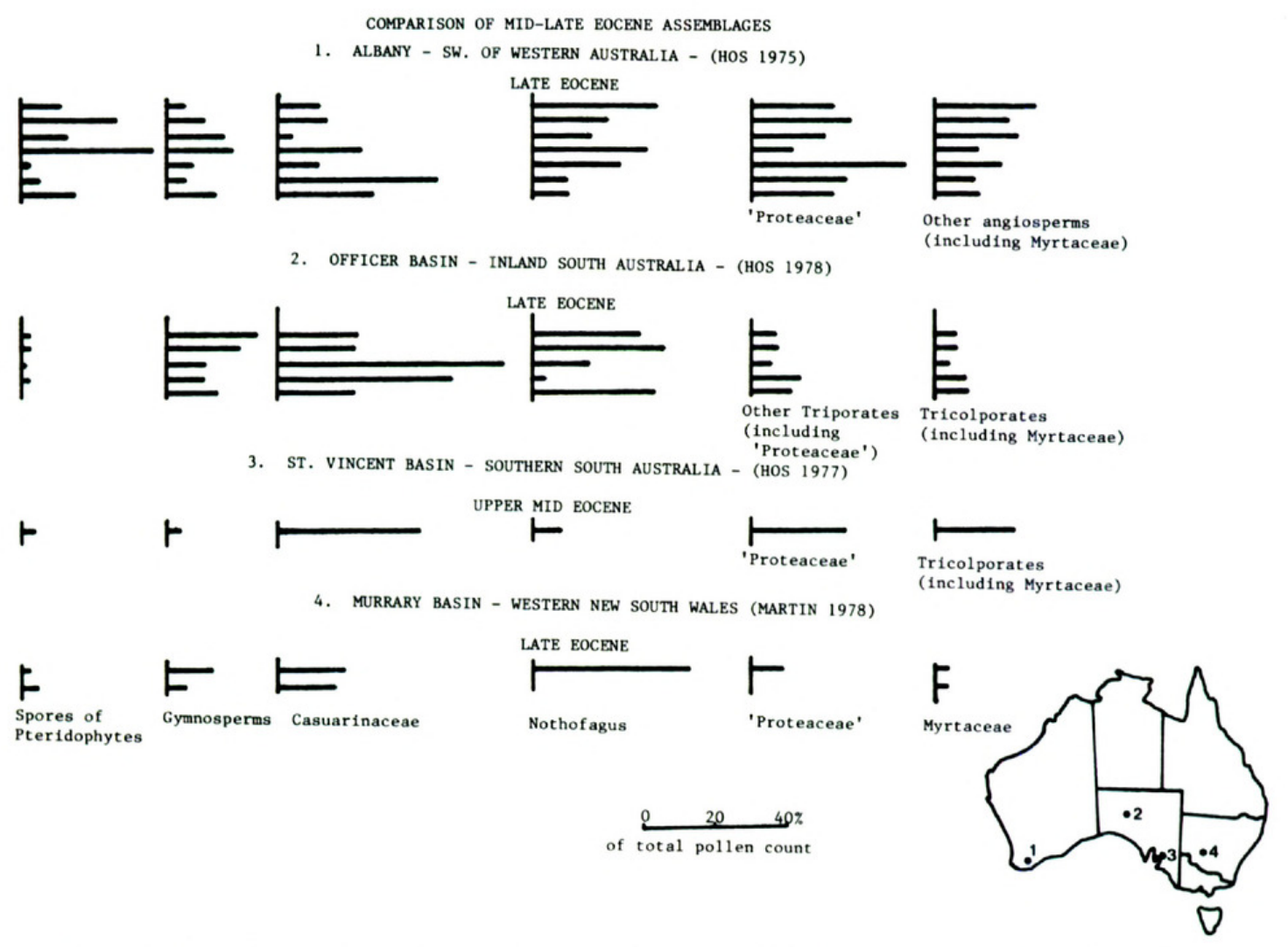

Figure 10. Comparison of the abundant pollen groups, in the mid-late Eocene. Spores of pteridophytes and 'Proteaceae' are more abundant at Albany. Casuarinaceae is less abundant in the Murray Basin, the easternmost location.

shows one of the fusca pollen type, Nothofagus flemingii, plotted in the same way. While the percentage of the Nothofagus group varies little, N. flemingii shows two peaks of greater abundance, one in the early Oligocene and the other probably in the early Miocene. These two peaks in N. flemingii abundance may be recognized in the same stratigraphic position over the whole area studied. These examples illustrate how the grouping of the taxa in Fig. 9 may mask the variation present.

The ratio of Myrtaceae to Nothofagus pollen is presented in Fig. 13 and shows a gradual increase where the sampling interval is sufficiently close. This increase in Myrtaceae is earlier and more marked in bores to the west than those in the south and east of the study area, which is approximately $250 \mathrm{~km} \times 250 \mathrm{~km}$ (Martin, unpubl.).

Mid-late Miocene Comparisons. Figure 14 shows that the Myrtaceae reaches the highest values in the Castlereagh River Valley and Jemalong Gap-the two most westerly locations. Latrobe Valley in the most southeastern part of Australia has lower values for Myrtaceae. A reciprocal pattern is seen with Nothofagus, highest in the southeast and it has practically disappeared from Queensland. In the Latrobe Valley, two definite habitats may be identified in the coals; (1) open water, which accumulates mainly wind blown pollen and especially Nothofagus and (2) swamp, accumulating pollen from the plants on site as well as wind blown 

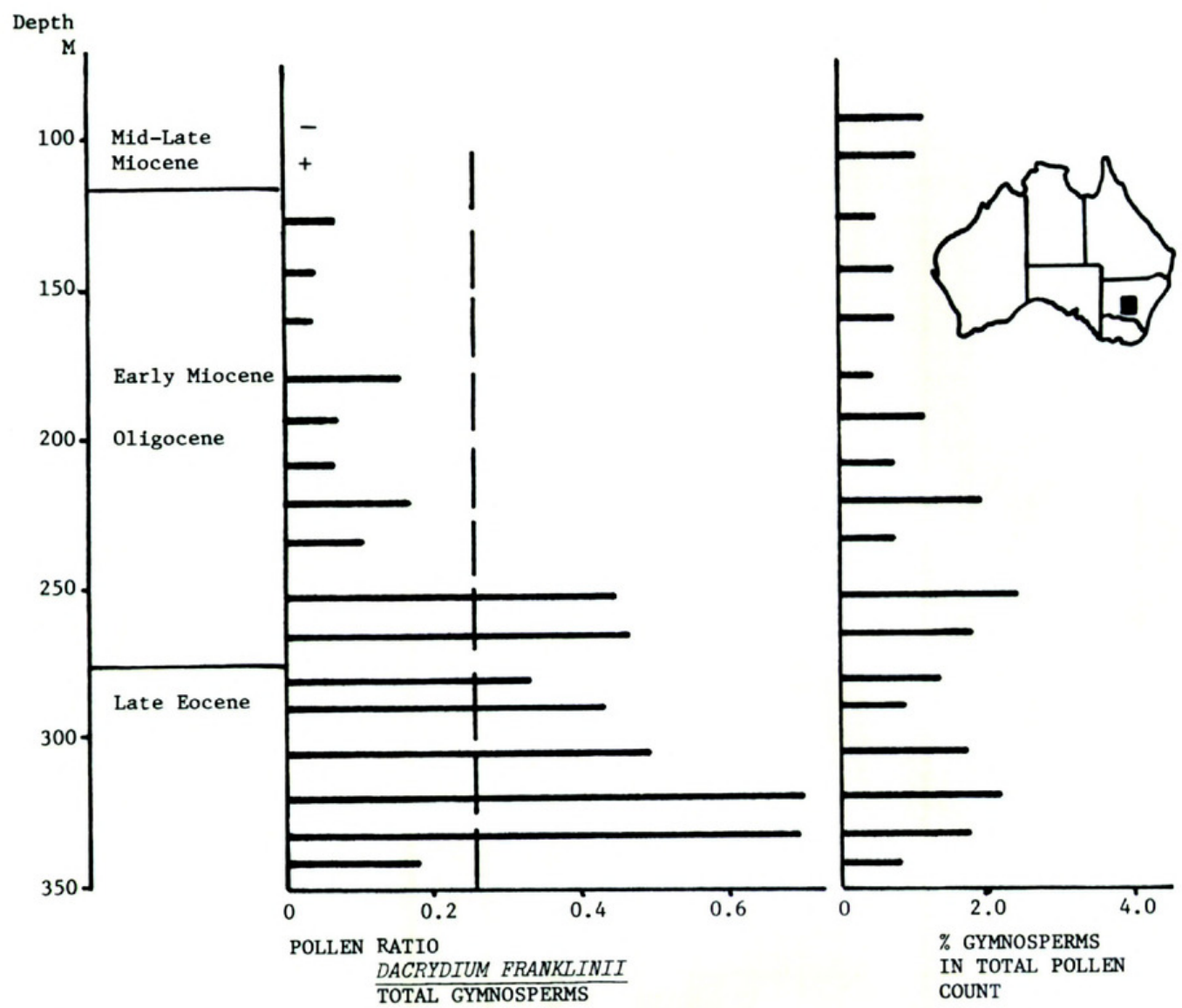

FIgURE 11. The ratio of Dacrydium franklinii to total gymnosperms. While the percentage of gymnosperms varies little, $D$. franklinii is the most abundant in the late Eocene-early Oligocene.

pollen. The latter has appreciable quantities of Restionaceae/Centrolepidaceae pollen (Luly et al., 1980). Macrofossils indicate a sclerophyllous vegetation in these swamp habitats (Blackburn, 1980). Assemblages from the Namoi and Castlereagh River Valleys may be very rich in unidentified tricolpate/tricolporate pollen types. Most of the taxa that can be identified in the latter sites are found today on the east coast of northern New South Wales and it is thought that the late Miocene vegetation here was more akin to the subtropical rainforest (Martin, 1980, 1981). Compositae, Gramineae, and the chenopod pollen type (Chenopodiaceae and Amaranthaceae) are present in low frequencies to the north.

Pliocene Comparisons. Figure 15 shows that the Myrtaceae was more abundnat to the west, in Jemalong Gap. Gymnosperms may be quite abundant and particularly the Araucariaceae, which may reach $50 \%$ of the total count on the Mooki River Valley. It is not clear whether the Araucariaceae was abundant in the Queensland site, for there is a problem of identification with the fossil pollen type Dilwynites granulatus, which may belong to the Araucariaceae but is also like Cinnamonum (Harris, 1965a). It is thought that these assemblages with high Araucariaceae are akin to the present day low microphyll vine forests with emergent Araucaria ('hoop pine scrubs') of southeastern Queensland. There is a little Nothofagus in the Pliocene, mostly the menzeisii and fusca pollen types. The 

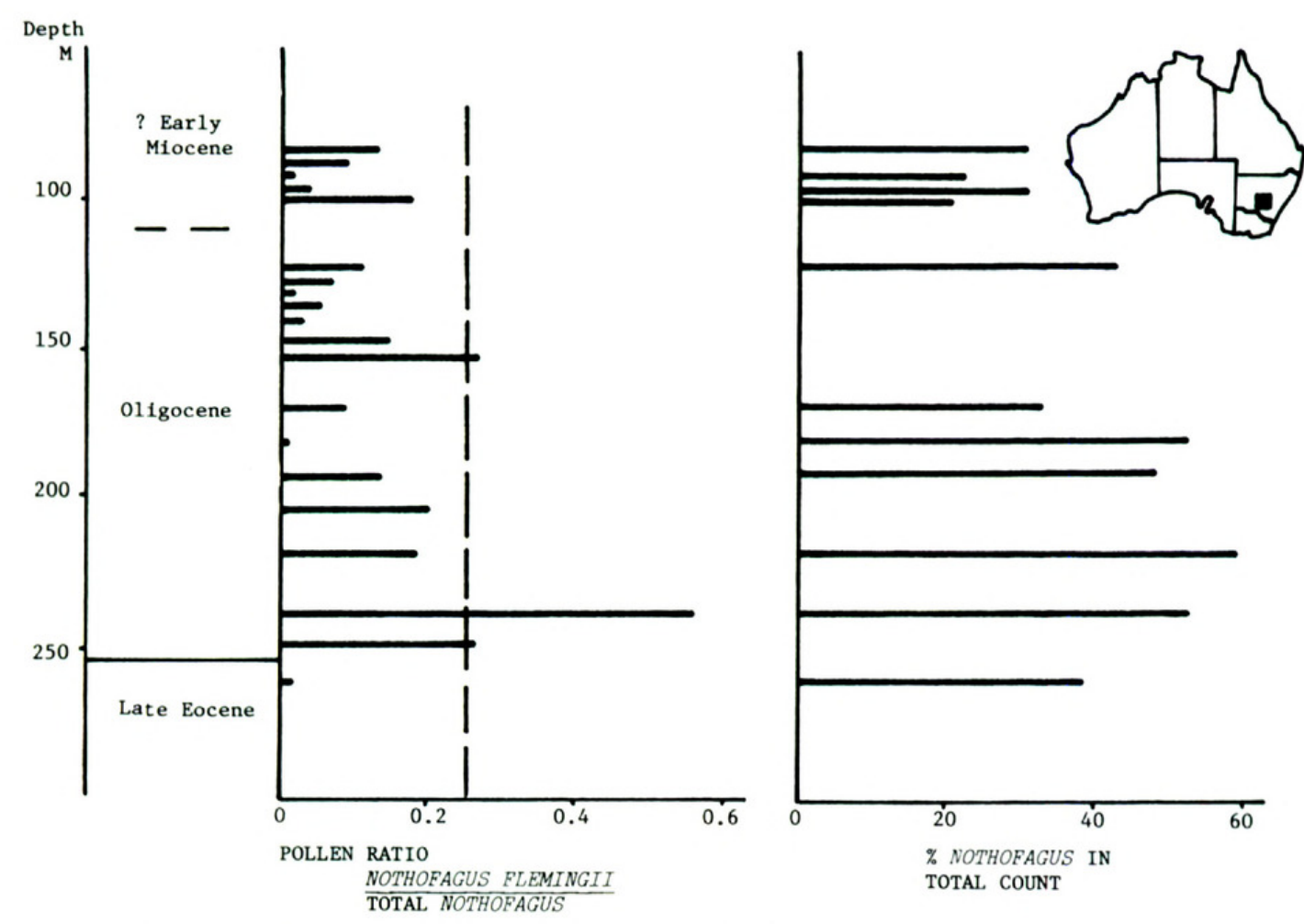

Figure 12. The ratio of Nothofagus flemingii to total Nothofagus pollen. There are two peaks where the ratio exceeds 0.25 , indicating change within the Nothofagus flora.

brassii type, which accounts for the greatest proportion of the Nothofagus count up to the mid-Miocene, is occasionally present but in very minor amounts, 1$2 \%$. Such small quantities could result from long distance dispersal or reworking of the older Tertiary sediments. Nothofagus in the Pliocene may be traced over most of southern New South Wales where it forms a valuable stratigraphic datum plane, but it is rarely encountered in the northern regions (Mooki and Castlereagh River Valleys). Compositae may be abundant, particularly to the north. The samples from Jemalong Gap with the high Compositae may be close to the Pleistocene boundary, judging by their distance above the Nothofagus horizon. Gramineae is usually present but not abundant and the chenopod pollen type is more abundant in the Queensland assemblage. In southwestern Australia, Myrtaceae or Casuarinaceae may be abundant. Restionaceae is usually well represented and Gyrostemon is important in some samples. Pteriodophytes and gymnosperms are rare.

Other reports give further indication of variation across Australia at different time intervals during the Tertiary. A pollen flora from Central Australia, $170 \mathrm{~km}$ northwest of Alice Springs, is reported to be mid-late Eocene in age by Kemp (1976). It has many features in common with those of southeastern Australia, but there are some differences. Cupressaceae, Cyperaceae, and Micrantheum, which are found in the Central Australian assemblages (Kemp, 1976), are rarely seen in southeastern Australia until the late Miocene-Pliocene. Early-mid Miocene assemblages near Lake Frome in inland Australia contain abundant grass pollen and have been interpreted as representing riverine rainforest with grasslands or 

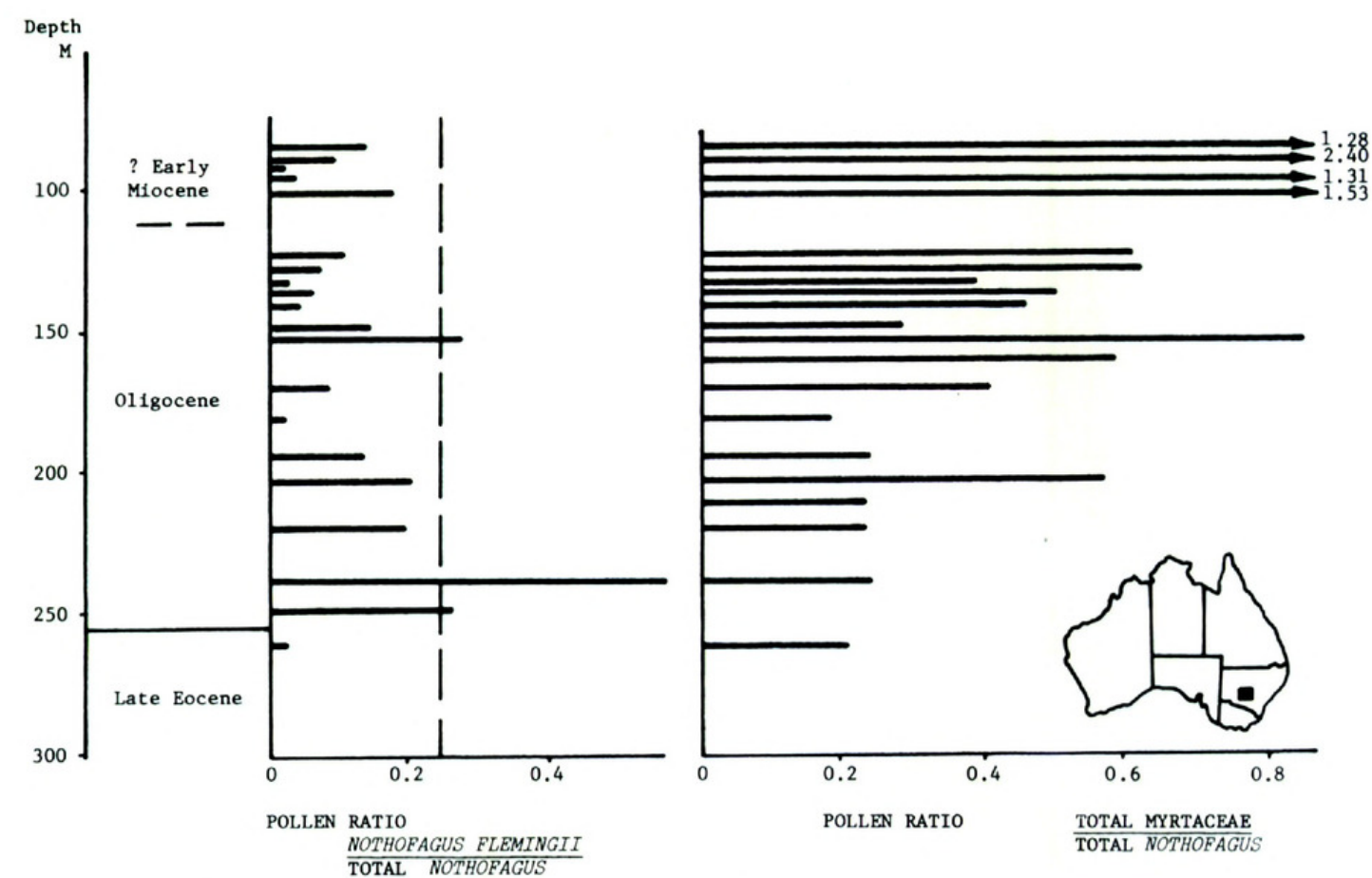

Figure 13. The ratio of Myrtaceae to Nothofagus pollen. There is an increase in the early Miocene, indicating a replacement of Nothofagus by Myrtaceae as the abundant pollen type.

grassy woodlands on the drier slopes and hillsides (W. K. Harris, pers. comm. in Callen \& Tedford, 1976). This contrasts with southeastern Australia where grasslands did not develop until the Pleistocene (Martin, 1969). These Central Australian records probably indicate the early stage of desiccation and contraction of closed forests. Unfortunately, once a dry climate or a strong seasonal climate is established, the permanently wet bogs, lakes, etc., which are necessary for preservation of plant material, disappear so there is no record of the development of the arid flora.

Queensland assemblages have been compared with others where relevant, but there are other differences as well. Anacolosa and Santalum pollen types, which disappear from southeastern Australia by the end of the Eocene, are found in early Miocene assemblages in Queensland. Nothofagus does not become abundant until early Miocene time, and the peak is short lived. It is thought that this Miocene peak is associated with a climatic change or uplift (Hekel, 1972) and suggests that the north was not as suitable for Nothofagus.

Comparisons with Quaternary Changes. The Tertiary shows the development of the flora and vegetation to roughly the present day status. In contrast to the Tertiary, the Quaternary shows changes within what is essentially the present day flora and vegetation. Nevertheless, these changes have been quite considerable, for while reasonable analogues of the fossil pollen assemblages may be found in the present vegetation, they are not precise and indicate that plant communities of even 10,000 years ago may no longer exist today.

There have been some extinctions on the Australian mainland as well, for example, Dacrydium Sect. B (cf. D. cupressinum) in northeastern Queensland 
COMPARISON OF MID-LATE MIOCENE ASSEMBLAGES

1. Aquarius Bore, Queensland (Hekel 1972)

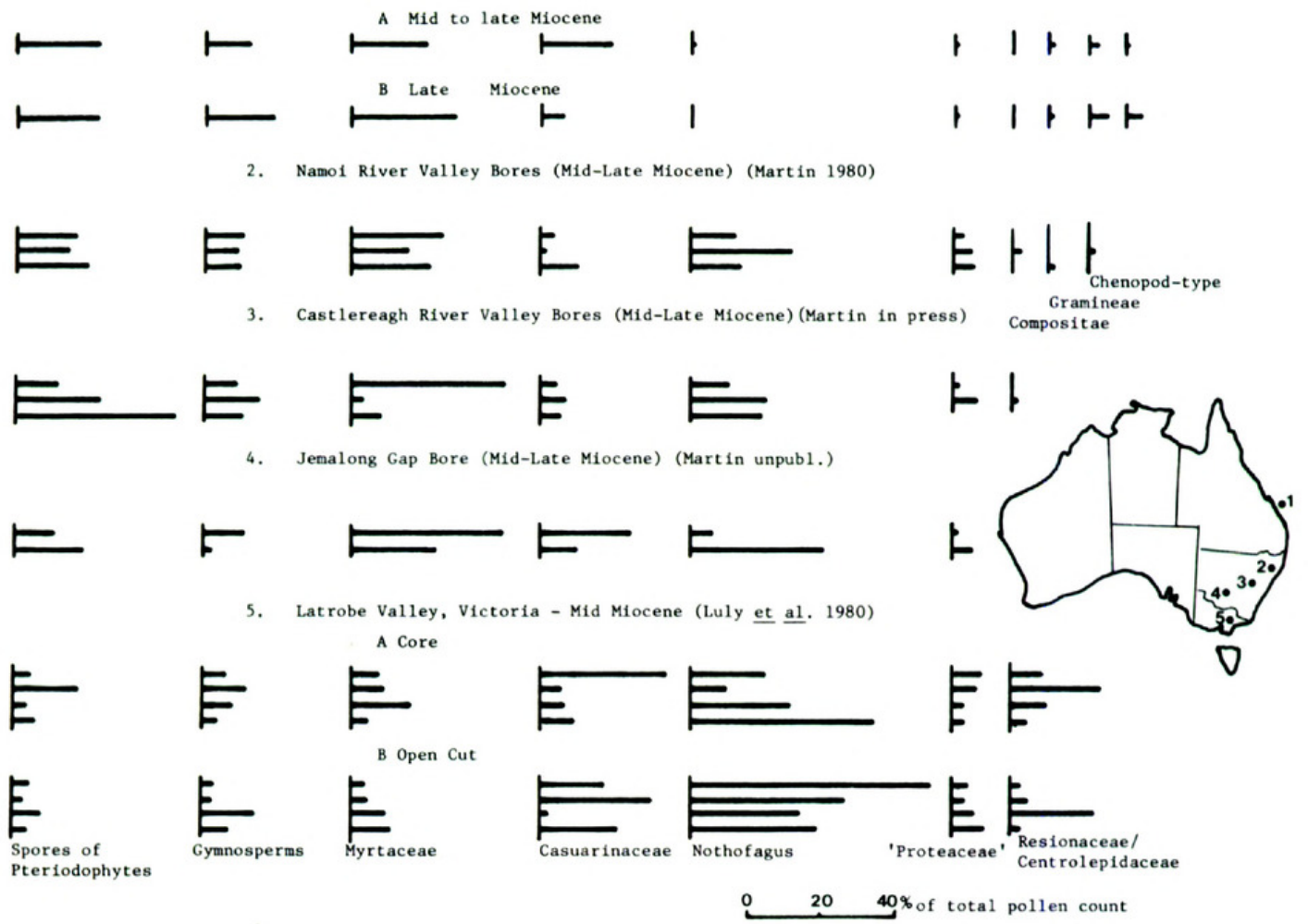

Figure 14. Comparison of mid-late Miocene assemblages. Myrtaceae is least abundant in Latrobe Valley, the southern-most site. Nothofagus is most abundant at the same site. Restionaceae and other sclerophyllous taxa are important in the Latrobe Valley (see Text for further discussion).

up to about 25,000 years B.P. (Kershaw, 1978), Dacrydium Sect. B and Podocarpus Section Dacrycarpus in northeastern New South Wales, in the Pleistocene (Martin, unpubl.) and Phyllocladus in Holocene southwestern Victoria (Dodson, 1974; Churchill \& Dodson, 1980). Of the many Quaternary records (Kershaw, 1981), only the two that extend back to the last interglacial period of 125,000 years ago or beyond will be mentioned here.

Lake George in the Eastern Highlands has the longest pollen record of 350,000 years. There are four wooded periods alternating with five non-wooded periods (Singh et al., 1981a, 1981b) and these periods correspond to interglacials and glacials, respectively. The character of the wooded periods changes from wet sclerophyll in the oldest to open sclerophyll and finally dry sclerophyll in the youngest and present wooded period. In an intriguing study of fire history, as reconstructed from the abundance of charcoal particles, fire frequency is always higher in the wooded periods, but increases along with the development of open sclerophyll during the last glacial period. During the non-wooded period of the last interglacial, the fire frequency does not drop, unlike the preceding three nonwooded periods, and this is attributed to Aboriginal man's activities (Singh et al., 1981a).

A record of 123,000 years in northeastern Queensland extends back to the last interglacial period. There is a full cycle of change in which the oldest 


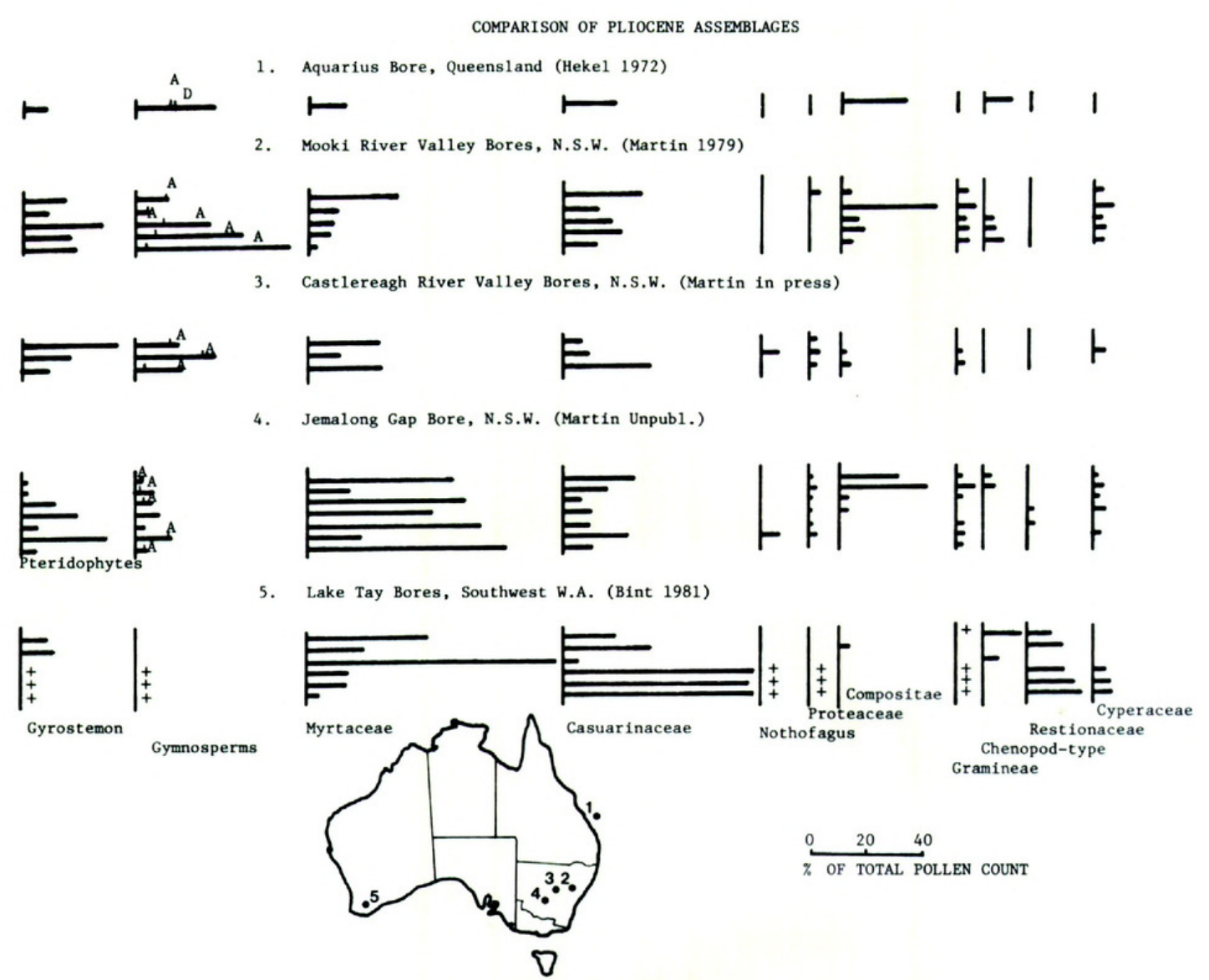

Figure 15. Comparison of Pliocene assemblages. $\mathrm{A}=$ Araucariaceae; $\mathrm{D}=$ Dilwynites granulatus; which may have affinities with the Araucariaceae (see Text). Araucariaceae may be abundant in Mooki and Castlereagh River Valleys. Myrtaceae is the most abundant in Jemalong Gap, the western-most site.

and youngest part of the profile are similar, with rainforest angiosperms the major group. The intervening period shows an increase of rainforest gymnosperms then sclerophyllous taxa, with the latter accounting for almost all of the pollen in the sediments of the last glacial period (Kershaw, 1978). The last 20,000 years of this pollen diagram are in agreement with the models proposed by Nix and Kalma (see Fig. 6).

In summary, where the Quaternary record extends back far enough, it shows periods in which two types of vegetation alternate; these periods may be linked with the glacial/interglacial cycles. Vegetation of a drier environment or of a more open nature is always found during the glacial times. The vegetation shows progressive change with the repetition of the cycles. There is some evidence of the effect of man on the vegetation through his penchant for starting fires. The oldest confirmed date for the presence of man in Australia is 32,000 B.P. (Barbetti \& Allen, 1972), but he may have been present at 40,000 B.P. or even earlier (Bowler, 1976).

\section{COMPaRisons With NeW ZEALAND}

Mildenhall (1980) has reviewed the Cenozoic plant biogeography of New Zealand and made comparisons with Australia. The main points are summarized here.

The late Cretaceous floras of Australia and New Zealand are very similar. 
The same palynological zones and datum planes may be used. Nothofagus appears in the late Cretaceous in Australia, New Zealand, and South America, and is scarce. In the Paleocene, podocarps are very common, all three pollen groups of Nothofagus are present but not abundant. Proteaceae, Casuarina, and the fusca pollen type of Nothofagus are the next most common to the podocarps. Myrtaceae appears in the Paleocene. The assemblages are essentially temperate, with rare occurrences of some tropical elements, e.g. Anacolosa and palm pollen. The Paleocene floras are similar to those of the late Cretaceous.

The Eocene is a time of widespread change, just as it is in Australia, and many new forms appear. Nothofagus becomes dominant, supplanting the podocarps. First the fusca group becomes more abundant, followed by the brassii group. Phyllocladus and pollen of Podocarpus section Dacrycarpus appear in the Eocene and there is an increased diversity in the Proteaceae and other angiosperms. At the end of the Eocene, the tropical and subtropical elements disappear, e.g. Anacolosa and the palms, including Nypa.

In the Oligocene, the brassii type of Nothofagus is dominant, with Casuarina often abundant. Myrtaceae, palms, podocarps, and the fusca type of Nothofagus are also prominent. Although Dacrydium franklinii is present, an abundance in the early Oligocene comparable to some of the high values seen in southeastern Australia has not been found in New Zealand. The Macaranga-Mallotus pollen type (Euphorbiaceae) may have been locally abundant. There is an increase in temperate taxa and a decrease in species diversity probably as a result of continued cooling.

In the early Miocene, low lying swamps are common in which Sparganium and palm pollen are abundant. The flora is very rich, indicating subtropical forests. The assemblages are dominated by the brassii type of Nothofagus, Myrtaceae (including ? Eucalyptus), Casuarina, podocarps, and Macaranga-Mallotus. The late Miocene shows a dramatic change with many herbaceous taxa appearing (Mildenhall, 1980). Acacia also appears in the early Miocene, approximately the same time as its first appearance in Australia (Pocknall, 1981) and temperate taxa become prominent in most assemblages. The brassii type of Nothofagus is still common and occasionally dominant, as is Casuarina, but the fusca type of Nothofagus and podocarps are more often dominant. Many new taxa appear in the Miocene.

In the Pliocene, a mosaic of different forest types occurs, both in space and time. Glaciation reduces some forests to scrubland or grassland. The brassii pollen type of Nothofagus is still prominent in the north. Palm pollen ceases to be important in the early Pliocene. Ferns become more diverse and abundant. In the South Island, middle Pliocene assemblages contain abundant grasses, Compositae, and other herbaceous taxa, indicating grassland. There is, however, a wide range of floral characteristics indicating rapid environmental change. Many tropical taxa disappear during the Pliocene. Many of the taxa appearing in the Miocene disappear before the Pleistocene glaciations. A number of shrubby and herbaceous taxa appear, including Acacia, which disappears from New Zealand in the Pleistocene. In the Pleistocene repeated glaciations wipe out many taxa.

Mildenhall (1980) also cited a number of examples of trans-Tasman migration. One of the best examples is seen in the different pollen types of Nothofagus. 
TABLE 1. Comparison of first appearances in Australia and New Zealand.

\begin{tabular}{|c|c|c|}
\hline \multicolumn{3}{|c|}{ Taxa Appearing First in Australia } \\
\hline & \multicolumn{2}{|c|}{ First Appearance } \\
\hline & Australia & New Zealand \\
\hline Ilex & Late Cretaceous & Eocene \\
\hline Nothofagus flemingii & Paleocene & Late Eocene \\
\hline N. falcata & Mid-Eocene & Oligocene \\
\hline Polycolpites reticulatus & Early Eocene & Late Eocene \\
\hline Restionaceae, 'Restio' pollen type & Early Eocene & Mid-Eocene \\
\hline Micrantheum & ? Eocene ${ }^{1}$ & Late Mio-Pliocene \\
\hline Macaranga-Mallotus & ? Eocene ${ }^{2}$ & Oligocene \\
\hline Polygalaceae (Polycolpites esobalteus) & Early Eocene & Miocene \\
\hline Banksia & Early-mid-Paleocene & Late Eocene \\
\hline \multicolumn{3}{|l|}{ Bombacaceae (Bombacacidites } \\
\hline bombaxoides) & Early Eocene & Late Eocene \\
\hline Cyperaceae & ? Eocene & Oligocene \\
\hline Cunoniaceae & Eocene $^{3}$ & Oligocene \\
\hline 'Randia' chartacea & Mid-late Miocene & Early-mid-Pliocene \\
\hline
\end{tabular}

Taxa Appearing First in New Zealand

\begin{tabular}{|c|c|c|}
\hline \multicolumn{3}{|c|}{ Taxa Appearing First in New Zealand } \\
\hline & New Zealand & Australia \\
\hline $\begin{array}{l}\text { Nothofagus, menziesii type } \\
\text { Anacolosa }\end{array}$ & $\begin{array}{l}\text { Paleocene } \\
\text { Paleocene }\end{array}$ & $\begin{array}{l}\text { Early Eocene } \\
\text { Eocene }\end{array}$ \\
\hline
\end{tabular}

Time ranges from Mildenhall (1980), Stover and Partridge (1973), and ${ }^{1}$ Kemp (1976), ${ }^{2}$ Martin (unpubl.), ${ }^{3}$ Christophel (pers. comm.).

Some types appear first in Australia, some first in New Zealand (see Table 1). Because Nothofagus has a very limited seed dispersal (see Martin, 1977b), Mildenhall thinks that long distance dispersal has been accomplished by means of viable pollen to a still receptive gene pool (i.e. windblown pollen from Australia fertilized female flowers in New Zealand). Table 1 lists the taxa common to Australia and New Zealand that appear first in Australia and first in New Zealand. Although not all-inclusive, more taxa make their appearance first in Australia than in New Zealand. Work in progress will change some of the time ranges, but the general conclusion that a number of taxa appear first in Australia will probably remain valid (D. Pocknall, pers. comm.). There are many other taxa that appear about the same time in both. As discussed previously, Australia and New Zealand have remained at approximately the same distance apart, $2,000 \mathrm{~km}$, throughout the Cenozoic, although there have been relative changes in latitude.

\section{Comparison with Southeast Asia}

The most complete record comes from Borneo. Paleocene-Eocene floras of Borneo are distinctive and $60 \%$ have not been recorded outside of Sarawak. Twenty-six percent of the remainder are world wide. Only $11 \%$ can be referred to living genera. Nine percent are exclusively pantropical. One pollen type has northern hemisphere affinities. None of the extremely characteristic Australian groups such as Proteacidites, Nothofagus, or the southern hemisphere gymno- 


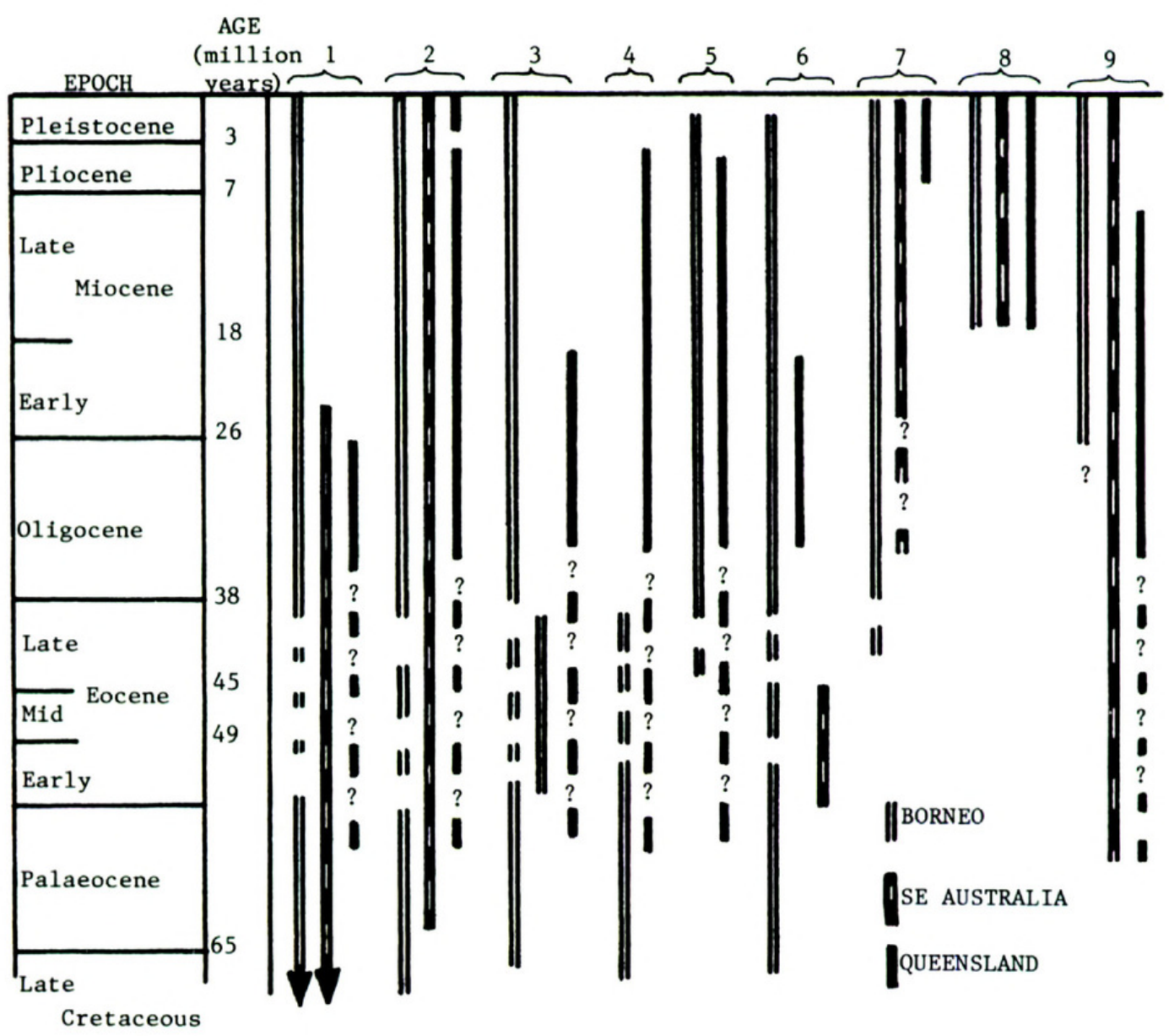

Figure 16. Pollen taxa common to Borneo and Australia in the early Tertiary. The broken line for Queensland through the Eocene and into the late Paleocene indicates imprecise dating (see Text for further discussion). The Eocene of Borneo is poorly known (J. Muller, pers. comm.) hence is represented by the broken lines. The numbers represent taxa, see Table 2.

sperms are present. When compared with the latitudinal equivalents in Africa and South America, the Bornean floras are rather depauperate in contrast to the present day, where it has the richest floras (Morley, 1977). Thus the early Tertiary floras of Borneo were very different to those of Australia, as would be expected from the $3,000 \mathrm{~km}$, latitudinally, between the two regions. However, there are a few taxa in common and these are shown in Fig. 16, in which floras of Borneo, Queensland, and southeast Australia are compared (Table 2). Unfortunately, the early Tertiary unit from Queensland is not dated more precisely than Paleocene to Oligocene (Hekel, 1972) (although it probably covers this time range), and this is shown by the broken line on Fig. 16. The Ilex pollen type, which has had a world wide distribution since the beginning of the late Cretaceous (Martin, 1977b), is present in Borneo, Queensland, and southeast Australia. Myrtaceae is found in Borneo, Africa, and South America in the Cretaceous (Muller, 1981), before its first appearance in southeast Australia in the Paleocene (Stover \& Partridge, 1973). It is rare in the pre-Miocene of Borneo. In the early Miocene there is a marked increase and it remains abundant thereafter (Muller, 1972), just as it does in southeast Australia. It is also present in the oldest Tertiary flora in Queensland. 
TABLE 2. Pollen common to Borneo, Queensland, and SE Australia in the Tertiary. Key to the taxa shown in Fig. 16.

\begin{tabular}{|c|c|c|}
\hline Botanical Affinity & Fossil Name(s) & References \\
\hline 1. Ilex & $\begin{array}{l}\text { Gemmatricolporites permagem- } \\
\quad \text { matus } \\
\text { Ilexpollenites spp. }\end{array}$ & $\begin{array}{l}\text { Muller, } 1968 \\
\text { Martin, 1977b; Hekel, } 1972\end{array}$ \\
\hline 2. Myrtaceae & Myrtaceidites spp. & $\begin{array}{l}\text { Muller, 1968; Stover \& Partridge, } \\
\text { 1973; Hekel, } 1972\end{array}$ \\
\hline 3. Anacolosa & Anacolosidites spp. & $\begin{array}{l}\text { Germeraad et al. 1968; Stover \& } \\
\text { Partridge, 1973; Hekel, 1972; } \\
\text { Harris, 1965b. }\end{array}$ \\
\hline 4. Unknown & Striatocolporites minor & Muller, 1968; Hekel, 1972 \\
\hline 5. Rhizophoraceae & Zonocostites ramonae & $\begin{array}{l}\text { Germeraad et al., 1968; Hekel, } \\
1972\end{array}$ \\
\hline 6. Nypa & $\begin{array}{l}\text { Spinozonocolpites prominatus }= \\
\quad \text { S. echinatus }\end{array}$ & $\begin{array}{l}\text { Muller, 1968; Stover \& Evans, } \\
\text { 1973; Hekel, } 1972\end{array}$ \\
\hline 7. Alchornea-Coelebogyne & Psilatricolporites operculatus & $\begin{array}{l}\text { Germeraad et al., 1968; Martin, } \\
\text { 1974; Hekel, } 1972\end{array}$ \\
\hline 8. Compositae & $\begin{array}{l}\text { Echitricolporites spinosus } \\
\text { Tubulifloridites antipodica }\end{array}$ & $\begin{array}{r}\text { Germeraad et al., 1968; Stover \& } \\
\text { Partridge, 1973; Hekel, } 1972\end{array}$ \\
\hline $\begin{array}{l}\text { 9. Austrobuxus }(=\text { Longe- } \\
\text { tia)-Dissiliaria }\end{array}$ & Malvacipollis diversus & $\begin{array}{l}\text { Muller 1972; Stover \& Partridge, } \\
\text { 1973; Hekel, } 1972\end{array}$ \\
\hline
\end{tabular}

Anacolosa does not appear in northeast Queensland until the late Oligocene (Hekel, 1972), although it is present in the Paleocene Brisbane microfloras of southeast Queensland (Harris, 1965b). Other pollen types found in both Borneo and Queensland before the Miocene are shown also in Fig. 16 (Muller, 1968; Germeraad et al., 1968; Hekel, 1972) and include Rhizophoraceae, Nypa, Alchorneal Coelebogyne, and Compositae. In southeastern Australia in the early Eocene, at a time of low sea level, Nypa probably formed extensive mangrove forests on the exposed continental shelf, particularly in the Bass Strait between Tasmania and mainland Australia. A rapid rise in sea level subsequently inundated these forests (Partridge, 1976).

Mangrove pollen of the Sonneratia type and Rhizophoraceae become important in Borneo in the Oligocene. The ancestral type of Sonneratia may extend into the latest Eocene. Nypa and the Brownlowia-type pollen are the only mangroves present in the Eocene, perhaps suggesting that mangrove vegetation was not well developed then. In the late Miocene, other mangrove taxa become important. These include Acanthus, Aegialites, Avicennia, and Camptostemon. There is thus a history of the gradual appearance of the modern mangrove vegetation (Muller, 1964; Morley, 1977).

Pollen of Asiatic montane taxa become common and abundant in the Oligocene-early Miocene of Borneo. These taxa include Pinus, Picea, Tsuga, and Alnus. Some of these pollen types are notorious for long distance dispersal but their abundance indicates that they must have been growing locally. The montane pollen is found in assemblages with the tropical lowland mangrove pollen. Geological evidence indicates mountain building in the areas bordering the depositional basins, and that these mountains had been reduced by erosion by the late 
Miocene when there was further upıft (Muller, 1966, 1972). Apart from these selected taxa, there are no other published accounts of Oligocene floras for southeast Asia.

A Miocene coal from Borneo has been studied in detail and compared with a Holocene peat and the present-day swamp vegetation. There are some 76 spore and pollen types and the floristic composition of the coal and peat is closely comparable. Any minor differences can be attributed to ecologic variation, etc. Only one pteridophyte spore, Stenochlaena areolaris, has become extinct since the Miocene (Anderson \& Muller, 1975) although it is present elsewhere in the Philippines today. Thus the flora takes on a modern aspect in the Miocene (Morley, 1977) and has remained much the same to the present day in this particular location. In the montane record, however, the austral taxa Podocarpus sect. Dacrycarpus and Phyllocladus appear in the late Pliocene-Pleistocene (Muller, 1966). In the Pliocene, pollen of Acanthaceae, Balsaminaceae, Compositae, Gramineae, and Loranthaceae increase in frequency and diversity (Morley, 1977). In the Quaternary, several lines of evidence indicate a more seasonal climate in the Sunda area (Morley, 1977) but the palynological record is very meager for this period.

In New Guinea, pollen floras from the Central Delta region of Papua extend back to the late Miocene and consist mostly of contemporaneous taxa. Spores of pteridophytes generally dominate the counts. Gymnosperms are present in very low frequencies and include Microcachrys and/or Microstrobus (which disappeared in the late Tertiary), Podocarpus section Dacrycarpus and other Podocarpus spp., Dacrydium, Araucariaceae, and probably the cycad-type. Of the angiosperm pollen, the mangroves Rhizophoraceae and Sonneratiaceae are the most abundant together with Palmae. Nothofagus, the brassii pollen type (now growing in the New Guinea highlands) is present but usually $10 \%$ or less of the total pollen counts, suggesting that it was probably transported into the area of deposition. There are a few grains of the fusca type of Nothofagus and it is uncertain whether this represents long distance dispersal or a rare presence in New Guinea. Small quantities of Rubiaceae, Proteaceae, Casuarinaceae, Myrtaceae, and Malvaceae are present (Khan, 1974). This region of New Guinea has always been part of the Australian plate. The oldest record, however, dates from a time when the southeast Asian and Australian plates were in contact. The pollen flora largely reflects the deltaic environment of deposition with some pollen being transported in from the surrounding regions.

\section{Discussion}

The Australian paleobotanical record shows major changes in the mid-late Eocene, the Miocene, and the end of the Pliocene. These changes coincide broadly with major declines in the oxygen isotope temperature curve (Fig. 4). The midlate Eocene changes are associated with the opening of the seaway south of Australia. The Miocene change is associated with the Antarctic ice-cap reaching major proportions and developing aridity in Australia. The changes at the end of the Pliocene are associated with the onset of the glacial cycles and aridity in Australia reaching its present dimensions. These changes are shown clearly in 
the abundant pollen groups shown in Fig. 9, but many of the low frequency pollen types show changes about the same time.

The Tertiary pollen assemblages show general and distinctive patterns for any one geological age. Some changes in the Australian flora through the Tertiary may be postulated thus:

Early Paleocene: Gymnosperms are probably the major element and angiosperms are still increasing in importance. There are many extinct taxa.

Late Paleocene-Eocene: 'Proteaceae' are more abundant and very diverse. This abundance is surprising, given the low pollen production of this taxon today (Martin, 1978). If these Tertiary 'Proteaceae' were trees, then more pollen would be produced when compared with a sclerophyllous shrub layer, especially if the trees were those of the high canopy (Birks \& Birks, 1980). Some proteaceous trees are found in Queensland rainforests today, but pollen counts are low (Kershaw, 1970b). It is possible that these ancient 'Proteaceae' were one of the dominants in the vegetation. Many of the taxa are extinct.

Late Eocene, Oligocene, and Early Miocene: Nothofagus is the dominant pollen type in the pollen assemblages but, given its heavy pollen production, it may not have been the dominant in the vegetation, although more abundant than formerly. Other low pollen producers that are usually present in the assemblages may have been just as abundant in the vegetation.

Miocene and Pliocene: Myrtaceae becomes the dominant. The eucalypt pollen type (which may include other genera) is present but not abundant, except perhaps in southwestern Australia (Bint, 1981), assuming reliable identification of Eucalyptus.

Late Pliocene and Early Pleistocene: The present floristic zones and vegetation probably became established about this time, but this assumption is based on the climatic evolution, for the fossil record is too scanty to support it. Besides these overall trends, there are shorter fluctuations in the pollen record (see Figs. 11,12 ), which are probably the result of climatic fluctuations, but the 'resolution' of dating is not sufficient to allow any correlation with a causal factor such as the oxygen isotope curve or sea level changes.

Most of the variation seen in the Tertiary assemblages is consistent with the hypothesis that there was a Tertiary climatic gradient parallel to that seen today, i.e. drier inland and wetter on the coast, particularly in the southeast corner of Australia. (The inland region was, however, relatively well watered through most of the Tertiary when compared with its present state.) Myrtaceae becomes abundant first in inland New South Wales and later in southeast Victoria, whereas Nothofagus declines first in Queensland, then inland Australia, and last in southeast Victoria, where small remnant stands of Nothofagus cunninghamii are still present today. The development of open woodland and/or savannah started first in Central Australia, then possibly in the north, and finally in southeast Australia. Some present-day patterns appear to be fore-shadowed even in the early Tertiary, following the climatic gradient. Dacrydium franklinii was more abundant in southeastern Victoria, during the late Eocene early Oligocene, close to its present distribution in Tasmania. Not all taxa fall into this category. Ilex found today across the north of Australia does not extend south of latitude $18^{\circ} 10^{\prime} \mathrm{S}$ in Queens- 
land yet it is present in the early Tertiary in southeast Australia when it was adjacent to Antarctica.

There are general similarities between the Australian and New Zealand paleobotanical record, even though these two land masses have remained at approximately the same distance of $2,000 \mathrm{~km}$ from each other throughout the Tertiary. The increase in abundance of Nothofagus in the Eocene is seen in both. New Zealand was as much affected by the opening of the seaway around Antarctica as was Australia, so these similarities are not surprising. The Miocene was also a time of major change in New Zealand, for it too was influenced by the ice cap development on Antarctica. However, the Miocene marks a divergence, New Zealand being subjected to heavy glaciation that probably started in the Pliocene whereas Australia suffered increased aridity. This difference probably results from New Zealand remaining at the same latitude whereas Australia continued on its path northwards, although a small, insular landmass such as New Zealand is not strictly comparable to a continental landmass. This floral similarity is illustrated by the extinct Tertiary angiosperm taxa in New Zealand. Of the 200 or so extinct taxa in the palynological record, $70 \%$ occur in the Australian record also. About $20 \%$ are restricted to New Zealand, mostly in the Miocene (Mildenhall, 1980).

The early Tertiary floras of southeast Asia and Australia are quite different although the evidence from northern Australia, the most relevant region in this context, is very scanty. This difference is to be expected for two reasons: the different floristic inheritance and the different climatic zones that must have existed with a latitudinal distance of $3,000 \mathrm{~km}$ between the two continents. There are, however, a few taxa in common with both continents, even with southeast Australia. The most notable common taxon is the Myrtaceae, which appears first in Borneo, before Australia. There are more taxa in common, from Miocene time when the two continents came into collision, but there remain many differences which may be attributed to environmental differences.

Today the dry monsoonal climate and infertile soils of northern Australia are very limited in New Guinea, whereas the habitats for the complex lowland humid rainforests of New Guinea are restricted to a "small archipelago" of habitats on the Australian mainland (Webb \& Tracy, 1972). Areas of seasonal drought and dry pockets are very restricted in the island archipelago of southeast Asia (see van Steenis, 1979, p. 107). This environmental difference is largely the result of different geological evolution, more active tectonism in New Guinea and elsewhere than on the Australian mainland. It is likely that this difference extended back into the Tertiary. With one published account for New Guinea and two for Queensland, the fossil record is too inadequate for further comparisons.

The increase in Myrtaceae in Borneo in the early Miocene, about the same time as it started increasing in Australia, is most interesting. The increase in Australia may be attributed to developing aridity, although independent evidence for the timing of this event is uncertain. However, it is unlikely that aridity was the cause of the increase in Borneo. In the vegetation of Borneo, Myrtaceae may be abundant on the infertile soils (J. Muller, pers. comm.). Although not studied in detail, Specht and Womersley (1979) described "heathlands" in Malesia. 'Heath forests' are considered as an edaphic climax rainforest developed on very infertile 
soils. With increasing site severity the forest is replaced by open scrubland. Species of Baeckea, Leptospermum, Eugenia, Tristania, Rhodamnia, Rhodomyrtus, and Xanthostemon of the Myrtaceae are involved. A diagram of the heath-forests and scrublands in Bako National Park, Sarawak, shows Tertiary Sandstone as the parent rock (Specht \& Womersley, 1979). Thus the increase in Myrtaceae in Borneo may be related to newly available infertile soils.

The hypothesis above, which accounts for the increase in Myrtaceae in Borneo, also questions the developing aridity as the cause of the increase in Australia. As discussed previously, there is evidence, such as quartz sands and gravels in the lower sediments in western New South Wales, that the soils may have been less fertile than those of today. Nothofagus and other rainforest taxa would have had to exist on these infertile soils as well as the Myrtaceae. However, some sites, such as narrow gullies, favor nutrient accumulation. In any given topography, a mosaic of soil fertility and available moisture would exist, even with a uniform parent rock material and climate (respectively). Consequently the different components of the pollen assemblage may not have been growing together, but the palynological method would not detect this. As discussed previously, adaptations to a low nutrient status lowers the growth rate, which appears to confer added drought resistance as well. Now, any taxon with a slower growth rate is at a serious competitive disadvantage if the climate is suitable for faster growing species. It is likely that the long history of infertile soils allowed the evolution of mechanisms of coping with infertility. Such taxa would be relegated to the most unfavorable sites while the climate was suitable for faster growing species, for some kinds of rainforest are capable of growing on relatively infertile soils, provided that rainfall is adequate (Webb, 1978). Once the climate started to become drier, the taxa on the unfavorable sites expanded their area. This expansion of Myrtaceae starts earlier in the west of western New South Wales, thus paralleling the climatic gradient. Independent evidence from the sediments, viz., that the carbonaceous content decreases about the time of the Myrtaceae increase, is interpreted as a decrease in swamp vegetation that would follow a drier climate. Most of the early Miocene Myrtaceae are not the Eucalyptus type. The whole assemblage indicates closed forest, even into the Pliocene and there is no known analogue in Australia for these myrtaceous forests. It is a matter for conjecture whether these Miocene-Pliocene myrtaceous closed forests were akin to the "heath forests" of Borneo today.

So far this paper has dealt with the barriers of water, topography, climate, soils, and distance. Reconstruction of the barriers of vegetation are more difficult because the palynological method is not suited for the detection of vegetation that may exist as a mosaic. Identifications are rarely to specific level and the ecological tolerances of a genus may encompass more than one vegetation type. It is possible to reconstruct the vegetation mosaic from the pollen assemblage, given incompatible ecological tolerances, but not with any great precision. Acacia in New Zealand provides a good example. In the early Miocene, Acacia is found on the eastern coast of the South Island in assemblages with abundant brassii pollen of Nothofagus. The whole assemblage indicates rainforests. Acacia is usually found in open vegetation, so it may have existed in exposed coastal situations subject to wind desiccation (Pocknall, 1981). However, there are a few 
species of Acacia that are found in certain rainforests today (Webb \& Tracy, 1981b) so this Miocene Acacia in New Zealand may have been a rainforest species also. Acacia appears in the Pliocene on the west coast of the North Island of New Zealand and beconıes extinct during the Pleistocene (Mildenhall, 1975). The pollen assemblages in which it is found indicate coastal swamp sedges together with scrub and grassland species. Tree pollen is relatively rare and trees may have been restricted to the surrounding hills. Thus this second occurrence of Acacia in New Zealand is more in agreement with the ecological requirements of most Australian species today. Obviously, interpretations of pollen assemblages rely on a knowledge of the pollen behavior of the present vegetation. In a southeastern Australian study of some surface samples from small pockets of rainforest in vast areas of eucalypts, the rainforest was hardly detectable, quantitatively. (This study has important implications, viz., that very small areas of a different kind of vegetation that are biologically very important, may be almost undetectable by the quantitative palynological method.) Moreover, Acacia, regarded as one of the dominants in the Eucalyptus vegetation, was not recorded in the surface samples (Ladd, 1979). Acacia is a low pollen producer with very limited dispersal and it is never found in any quantity. These are examples of the problems of interpretation of pollen assemblages, particularly those of Tertiary age for which the present vegetation is not a good analogue.

Long distance dispersal is a controversial subject, but experience with the paleobotanical record leads to the conclusion that it has occurred. The best illustration of this is the similarity of the Australian and New Zealand Tertiary record. It is not known how this was accomplished, for much of the knowledge gleaned from present day observations of dispersal seems inapplicable to the fossil record. The reason for this probably lies in the vast geological time where the million-to-one chance has probably occurred many times. There are, however, mechanisms that make long distance dispersal possible. Birds transport seeds either in the gut or stuck to feet and feathers (Carlquist, 1981). Some birds migrate regularly. Birds may travel long distances in relatively short times. An example may be seen in opportunistic waterfowl, which rapidly move into flooded areas in inland Australia. Flooding may occur anywhere in the arid region after exceptional rains. When the floodwaters dry up, the birds disperse to the coast (Braithwaite, 1975) or as far away as New Zealand, Christmas Island or MacQuarie Island (G. van Tets, pers. comm.). The second mechanism is wind. Raven (1973) quotes a number of direct measurements of transport by the prevailing westerly winds of pollen, dust, smoke, and possibly pathogens from Australia to New Zealand. The prevailing westerlies probably could transport small seeds but would be unlikely to carry larger seeds. However, birds also use winds and some (e.g. albatross) regularly circle the globe in these latitudes. In New Zealand, the more recently arrived land birds are almost exclusively Australian (McDowall, 1969). Tropical cyclones produce winds that are much stronger than those of the westerlies. Tracks of the cyclones in the Australian region generally travel across the north, down the west coast and down the east coast, some of the latter eventually end up in New Zealand (Coleman, 1972). New Caledonia is well within the cyclone area. Tropical cyclones cause a great deal of damage and create the disturbance that may allow new introductions to become established. They also 
carry birds off course. There are plovers in Tasmania and New Zealand, and it had long been assumed that they were the same. However, a more critical examination of the New Zealand plover showed its affinities with a Queensland form. It is thought that tropical cyclones assisted the plovers in their journey to New Zealand (G. van Tets, pers. comm.). It is not intended to pursue this topic further, but simply to establish the following points: (1) The paleobotanical record indicates long distance dispersal has occurred; (2) mechanisms exist for long distance dispersal; and (3) the vast geological time where the most unlikely of probabilities may have occurred a number of times. In any case, dispersal does not succeed unless the environment at the end of the journey is suitable for growth and establishment. It appears that the environment of New Zealand and Australia was sufficiently similar to allow long distance dispersal to succeed.

\section{CONCLUSIONS}

Throughout this study, climate emerges as the most important environmental factor, for changes in the paleobotanical and paleoclimatic records usually go together. It is doubtful whether climate has acted as a barrier within Australia, through most of the Cenozoic. The arid center, a conspicuous barrier today, only reached full development in the late Tertiary, some 2.5 million years ago. Through most of the Tertiary, habitats suitable for closed forest existed in central Australia, though not necessarily continuous. Although the center was relatively well watered, there is evidence of a Cenozoic climatic gradient parallel to that of today, i.e. drier in the center and wetter on the coast. Such a gradient would provide a diversity of habitats. There may have been a north-south temperature gradient during the Tertiary, judging from the greater abundance of Nothofagus in southeastern Australia when compared to Queensland, but there is no independent evidence to support this.

Climate appears to have been no great barrier between Australia and New Zealand. Both of these land masses have been in the same latitudinal zone through most of the Tertiary and subjected to the same major influences on climate, viz., proximity to and ice cap development on Antarctica. The paleobotanical record is generally similar through most of the Tertiary, becoming less similar in the Pliocene when glaciation becomes increasingly important in New Zealand. The difference in climate between Australia and Southeast Asia must have been a barrier, as would be expected from a latitudinal distance of $3,000 \mathrm{~km}$ in the early Tertiary. The paleobotanical records are quite different as well. There is evidence of very limited migrations after these two land masses came into collision in the Miocene, for the seasonally dry habitats, so widespread in Australia, are very restricted in Southeast Asia. As well, such seasonal habitats may have had a relatively late development.

Soil fertility has probably played an important role, in conjunction with climate. Although documentation of Cenozoic changes in fertility is sparse, the limited evidence suggests that, during the Tertiary, some soils were even less fertile than those of today. Adaptations to low fertility through a slower growth rate may enhance drought resistance. Hence some of the Tertiary flora may have possessed adaptations before the development of aridity. Low fertility soils are widespread in Australia but probably not so common in Southeast Asia. The 
increase in Myrtaceae in both Australia and Borneo is thought to be due to a combination of low fertility soils and perhaps developing aridity in Australia, but to newly available infertile soils in Borneo. That these two events both occur in the Miocene is probably only a coincidence.

The major topographic features in Australia have remained more or less the same through most of the Cenozoic. Tectonics have been very minor and gentle. Rather than acting as barriers, these factors have probably been important in maintaining habitat diversity. Tectonism has been more active in Southeast Asia, and topographic differences much greater, so these two factors may have been greater barriers to migration between Australia and Southeast Asia after these two plates came into collision.

Continental drift has had a major influence on the evolution of climate and this has been its most important effect within Australia throughout the Cenozoic. New Zealand has remained at approximately 2,000 km from Australia for the whole of the Cenozoic, but this distance appears to have had little effect as a barrier. The 3,000 km between Southeast Asia during the early Tertiary appears to be a barrier, which, however, may have been more of climate than of distance. After these two plates came into collision, there has been only limited migration, for the barriers of climate and soils remained and are seen today.

Barriers and migrations are concepts derived from historical biogeography, which is essentially the study of present day distributions. Historical biogeographers have traditionally held the hypothesis that a taxon originates somewhere (by evolution) and then spreads its range by dispersal, which may be stopped by barriers or channelled along migratory pathways. By closely studying some characteristics of the taxon and its distribution, they then work this hypothesis backwards to arrive at some explanation of how the present distributions came to be. The unstated assumption of this practice is: provided all other factors remain equal and stable. This study shows clearly that all other factors are not equal or stable, but that there is a complex, interwoven and continuously changing environment and flora. Although I have attempted to use the concepts of barriers and migrations, they seem inappropriate in this study, which essentially follows paleoecological principles.

\section{Literature Cited}

Alley, N. F. 1977. Age and origin of laterite and silcrete duricrusts and their relationship to episodic tectonism in the mid-north of South Australia. J. Geol. Soc. Austral. 24: 107-116.

Ambrose, G. J., R. A. Callen, R. B. Flint \& R. T. Lange. 1979. Eucalyptus fruits in stratigraphic context in Australia. Nature 280: 387-389.

Anderson, J. A. R. \& J. Muller. 1975. Palynological study of a Holocene peat and a Miocene coal deposit from N.W. Borneo. Rev. Paleobot. \& Palynol. 19: 291-351.

Ashton, D. H. 1981. Tall open forest. In R. H. Groves (editor), Australian Vegetation. Cambridge University Press, Cambridge.

Barbetti, M. \& H. Allen. 1972. Prehistoric man at Lake Mungo, Australia, by 32,000 BP. Nature 240: $46-48$.

Barker, P. F. \& J. Burrell. 1977. The opening of Drake Passage. Marine Geol. 25: 15-35.

BINT, A. N. 1981. An Early Pliocene pollen assemblage from Lake Tay, south-western Australia and its phytogeographic implication. Austral. J. Bot. 29: 277-291.

Birks, H. J. B. \& H. H. Birks. 1980. Quaternary Palaeoecology. Edward Arnold, London.

Bishop, P. \& R. W. Young. 1980. Discussion: on the Cainozoic uplift of the southeastern Australian highland. J. Geol. Soc. Austral. 27: 117-119. 
BlACKBURN, D. T. 1980. Floristic, environmental and lithotypic correlations in the Yallourn Formation, Victoria. In The Cainozoic Evolution of Continental Southeast Australia. Abstracts of papers presented at a symposium. Canberra, Nov. 1980. Bur. Miner. Resources \& Geophysics Record 1980/67.

- 1981a. Tertiary megafossil flora of Maslin Bay, South Australia: a numerical taxonomic study of selected leaves. Alcheringa 5: 9-28.

- 1981b. Plant fossils of the Latrobe Valley: a field guide. I. B.C., Sydney, 1981 Field trip 37 (unpubl.).

Bowen, G. D. 1981. Coping with low nutrients. In J. S. Pate \& A. J. McComb (editors), The Biology of Australian Plants. University of Western Australia Press, Nedlands.

Bowler, J. M. 1976. Aridity in Australia: age, origins and expression in Aeolan landforms and sediments. Earth Sci. Rev. 12: 279-310.

- G. S. Hope, J. N. Jennings, G. Singh, \& D. WAlker. 1976. Late Quaternary climates in Australia and New Guinea. Quat. Res. 6: 359-397.

BRaithwaite, I. W. 1975. Waterfowl on a dry continent. Natural History 81(5): 60-69.

Brown, D. A., K. S. W. Campbell \& K. A. W. Crook. 1968. The Geological Evolution of Australia and New Zealand. Pergamon Press.

Burbidge, N. T. 1960. The phytogeography of the Australian Region. Austral. J. Bot. 8: 75-212.

Butler, B. 1967. Soil periodicity in relation to landform development in southeastern Australia. In J. N. Jennings \& J. A. Mabbutt (editors), Landform Studies from Australia and New Guinea. Cambridge University Press, Casmbridge.

Callen, R. A. \& R. H. Tedford. 1976. New late Cainozoic units and depositional environments, Lake Frome area, South Australia. Trans. \& Proc. Roy. Soc. South Australia 100: 125-167.

Carlquist, S. 1981. Chance dispersal. Amer. Sci. 69: 509-516.

CHAPPELl, I. 1978. Chronologic methods and the ranges and rates of Quaternary physical changes. In D. Walker \& J. C. Guppy (editors), Biology and Quaternary Environments. Australian Academy of Science.

Christophel, D. C. 1980. Occurrence of Casuarina megafossils in the Tertiary of southeastern Australia. Austral. J. Bot. 28: 249-259.

Australia. Austral. J. Bot. 28: 249-259. palaeoclimate. In A. Keast (editor), Ecological Biogeography of Australia Vol. I. Junk, The Hague.

Hague. 1981 b. Early Tertiary megafossil floras of Australia. Abstract, XIII International Botanical Congress, Sydney.

Churchill, D. M. \& J. R. Dodson. 1980. The occurrence of Phyllocladus aspleniifolius (Lab. II) Hook. f. in Victoria prior to $1100 \mathrm{BP}$. Muelleriana 4: 277-284.

Coleman, F. 1972. Frequencies, tracks and intensities of tropical cyclones in the Australian region 1909 to 1969. Bureau of Meteorology, Commonwealth of Australia.

Coleman, P. J. 1980. Plate tectonics background to Biogeographic development in the southwest Pacific over the last 100 million years. Palaeogeo. Palaeoclim. Palaeoecol. 31: 105-121.

Cookson, I. C. 1947. On fossil leaves (Oleaceae) and a new type of fossil pollen grain from Australian brown coal deposits. Abstr. Proc. Linn. Soc. New South Wales 72: 183-197.

1954. The Cainozoic occurrence of Acacia in Australia. Austral. J. Bot. 2: 52-59.
- \& S. L. Duigan. 1950. Fossil Banksieae from Yallourn, Victoria, with notes on the morphology and anatomy of living species. Austral. J. Sci. Res., Ser. B., Biol. Sci. 3: 133-165.

\& \& 1951. Tertiary Araucariaceae from south eastern Australia, with notes on living species. Austral. J. Sci. Res., Ser. B., Biol. Sci. 4: 415-449.

\& K. M. PIKe. 1953a. The Tertiary occurrence and distribution of Podocarpus (section Dacrycarpus) in Australia and Tasmania. Austral. J. Bot. 1: 71-82.

Dacrycarpus . 1953b. A contribution to the Tertiary occurrence of the genus Dacrydium in the Australian region. Austral. J. Bot. 1: 474-484.

\& 1 1954. The fossil occurrence of Phyllocladus and two other podocarpaceous types in Australia. Austral. J. Bot. 2: 60-68.

Couper, R. A. 1960. New Zealand Mesozoic and Cainozoic plant microfossils. N.Z. Geol. Surv. Palaeont. Bull. 32.

Cowan, I. R. 1981. Coping with water stress. In J. S. Pate \& A. J. McComb (editors), The Biology of Australian Plants. University of Western Australia Press, Nedlands.

Crook, K. A. W. 1981. The breakup of the Australian-Antarctic segment of Gondwanaland. In A. Keast (editor), The Ecological Biogeography of Australia Vol. I. Junk, The Hague.

\& L. Belbin. 1978. The southwest Pacific area during the last 90 million years. J. Geol. Soc. Austral. 25: 23-40.

Curtis, W. M. 1956. The Student's Flora of Tasmania, Part I. Govt. Printer. Tas. 
Dodson, J. R. 1974. Vegetation and climatic history near Lake Keilambete, Western Victoria. Austral. J. Bot. 22: 709-717.

Duigan, S. L. 1950. A catalogue of the Australian Tertiary flora. Proc. Roy. Soc. Victoria 63: 41-56.

Fosberg, F. R. 1963. Plant dispersal in the Pacific. In J. L. Gressitt (editor), Pacific Basin Biogeography. Bishop Museum Press, Hawaii.

Francis, W. D. 1951. Australian Rainforest Trees. Forestry \& Timber Bureau, Commonwealth of Australia.

Galloway, R. W. \& E. M. Kemp. 1981. Late Cainozoic environments in Australia. In A. Keast (editor), Ecological Biogeography of Australia. Junk, The Hague.

GermeraAd, J. H., C. A. Hopping \& J. Muller. 1968. Palynology of Tertiary sediments from tropical areas. Rev. Palaeobot. Palynol. 6: 189-348.

Gill, A. M. 1981. Patterns and processes in open forest of Eucalyptus in southern Australia. In R. H. Groves (editor), Australian Vegetation. Cambridge University Press, Cambridge.

Gillison, A. N. \& J. Walker. 1981. Woodlands. In R. H. Groves (editor), Australian Vegetation. Cambridge University Press, Cambridge.

Graaf, J. W. E., van der, R. W. A. Crowe, J. A. Bunting \& M. J. Jackson. 1977. Relict early Cainozoic drainages in arid Western Australia. Z. Geomorph. N.F. 21: 379-400.

Groves, R. H. \& D. B. Williams. 1981. Natural grasslands. In R. H. Groves (editor), Australian Vegetation. Cambridge University Press, Cambridge.

Hamilton, W. 1979. Tectonics of the Indonesian region. U.S. Geol. Surv. Prof. Pap. 1078.

Harris, W. K. 1965a. Basal Tertiary microfloras from the Princetown area, Victoria, Australia. Palaeontographia B 115: 75-106.

_. 1965b. Tertiary microfloras from Brisbane, Queensland. Geol. Surv. Qld. Rept. No. 10.

HAYES, J. 1967. Land surfaces and laterites in the north of the Northern Territory. In J. N. Jennings \& J. A. Mabbutt (editors), Landform Studies from Australia and New Guinea. Cambridge University Press, Cambridge.

Hekel, H. 1972. Pollen and spore assemblages from Queensland Tertiary Sediments. Geol. Surv. Qld. Palaeont. Pap. 30: 1-31.

Hill, R. S. 1978. Two new species of Bowenia Hook. ex Hook. f. from the Eocene of Eastern Australia. Austral. J. Bot. 26: 837-846.

- 1980. Three new Eocene Cycads from eastern Australia. Austral. J. Bot. 28: 105-122.

Hos, D. 1975. Preliminary investigations of the palynology of the Upper Eocene Werillup Formation, Western Australia. J. Roy. Soc. Western Austral. 58: 1-14.

․ 1977. Eocene palynology of a sample from Golden Grove, South Australia. Dept. Mines \& Energy, South Austral. Rept. Bk. No. 77/88.

\&. 1978. Eocene palynology of Sadme Wilkinson No. 1, Eastern Officer Basin. Dept. Mines \& Energy, South Austral. Rept. Bk. No. 78/149.

Howard, T. M. 1981. Southern closed forests. In R. H. Groves (editor), Australian Vegetation. Cambridge University Press, Cambridge.

IDNURM, M. \& B. R. SEnIOR. 1978. Paleomagnetic ages of late Cretaceous and Tertiary weathered profiles in the Eromanga Basin, Queensland. Palaeogeog. Palaeoclim. Palaeoecol. 24: 263-277.

JeSSUP, R. W. \& R. M. NoRRIS. 1971. Cainozoic stratigraphy of the Lake Eyre Basin and part of the arid region lying to the south. Geol. Soc. Austral. 18: 303-331.

Johnson, R. W. \& W. H. Burrows. 1981. Acacia open forests, woodlands and shrublands. In R. H. Groves (editor), Australian Vegetation. Cambridge University Press, Cambridge.

Kemp, E. M. 1976. Early Tertiary pollen from Napperby, Central Australia. B.M.R. J. Austral. Geol. Geophys. 1: 109-114.

1978. Tertiary climatic evolution and vegetation history in the southeast Indian Ocean region. Palaeogeog. Palaeoclimatol. Palaeoecol. 24: 169-208.

- 1981. Tertiary palaeogeography and the evolution of climate. In A. Keast (editor), Ecological Biogeography of Australia. Junk, The Hague.

KENNETT, J. P. 1977. Cenozoic evolution of Antarctic glaciation, the Circum-Antarctic Ocean and their impact on global palaeoceanography. J. Geophys. Rev. 82: 3842-3860.

Kershaw, A. P. 1970a. Pollen morphological variation with the Casuarinaceae. Pollen \& Spores 12: $145-161$.

805 .

. 1970b. A pollen diagram from Lake Eramoo, northeast Queensland. New Phytol. 69: 785-

. 1978. Record of last interglacial-glacial cycle from northeastern Queensland. Nature 272: $159-161$.

1981. Quaternary vegetation and environments. In A. Keast (editor), Ecological Biogeography of Australia. Junk, The Hague. 
KHAN, A. M. 1974. Palynology of Neogene sediments from Papua (New Guinea). Stratigraphic boundaries. Pollen \& Spores 16: 266-284.

LADD, P. G. 1979. A short pollen diagram from rainforest in highland eastern Victoria. Austral. J. Ecol. 4: 229-237.

LANGE, R. T. 1978a. Carpological evidence for fossil Eucalyptus and other Leptospermeae (subfamily Leptospermoideae of Myrtaceae) from a Tertiary deposit in the South Australian Arid Zone. Austral. J. Bot. 26: 221-233.

1978b. Some Eocene leaf fragments comparable to Proteaceae. J. Roy. Soc. Western Austral. 60: $107-114$.

Leigh, J. H. 1981. Chenopod shrublands. In R. H. Groves (editor), Australian Vegetation: Cambridge University Press, Cambridge.

Loutit, T. S. \& J. P. KENNETT. 1981. Australian Cenozoic sedimentary cycles, global sea level changes and the deep sea sedimentary record. Oceanol. Acta S.P. Proceedings 26th International Geological Congress, Geology of Continental Margins symposium, Paris, July 7-17, 1980, pp. 45-63.

Luly, J., I. R. Sluiter \& A. P. Kershaw. 1980. Pollen studies of Tertiary brown coals: preliminary analyses of lithotypes within Latrobe Valley, Victoria. Monash publications in Geography No. 23, Monash University, Melbourne.

MarTin, H. A. 1969. The palynology of some Tertiary and later deposits in New South Wales. Ph.D. Thesis, Univ. New South Wales. (Unpubl.).

․ 1973. Upper Tertiary palynology in New South Wales. Geol. Soc. Austral. Spec. Pub. 4: 35-54.

1974. The identification of some Tertiary pollen belonging to the family Euphorbiaceae. Austral. J. Bot. 22: 271-291.

1977a. The Tertiary stratigraphic palynology of the Murray Basin in New South Wales. I. The Hay Balranald-Wakool Districts. J. \& Proc. Roy. Soc. New South Wales 110: 41-47.

1977b. The history of Ilex (Aquifoliaceae) with special reference to Australia. Evidence from pollen. Austral. J. Bot. 25: 655-673.

from pollen. Austral. J. Bot. 25 : $655-673$. pollen. Alcheringa 2: 181-202.

1979. Stratigraphic palynology of the Mooki Valley, New South Wales. J. \& Proc. Roy. Soc. New South Wales 112: 71-78.

. 1980. Stratigraphic palynology from shallow bores in the Namoi River and Gwydir Rivers, north central New South Wales. J. \& Proc. Roy. Soc. New South Wales 113: 81-87.

. 1981. Stratigraphic palynology of the Castlereagh River Valley, New South Wales. J. \& Proc. Roy. Soc. New South Wales 114: 77-84.

McDowall, R. M. 1969. Extinction and endemism in New Zealand land birds. Tuatara 17: 1-12.

McElhinny, M. W. 1970. Formation of the Indian Ocean. Nature 228: 977-979.

MCGowRAN, B. 1978. Stratigraphic record of Early Tertiary Oceanic and continental events in the Indian Ocean Region. Marine Geol. 26: 1-39.

- 1979. The Tertiary of Australia: foraminiferal overview. Marine Micropaleont. 4: $235-264$.

Mildenhall, D. C. 1975. Palynology of the Acacia bearing beds in the Kornako district, Pohangina Valley, North Island, New Zealand. New Zealand J. Geol. Geophys. 18: 209-228.

1980. New Zealand Late Cretaceous and Cenozoic plant biogeography: a contribution. Palaeogeog. Palaeoclim. Palaeoecol. 31: 197-223.

MorleY, R. J. 1977. Palynology of Tertiary and Quaternary sediments in Southeast Asia. Proceedings Indonesian Petroleum Association. Sixth Annual Conventions, May 1977, pp. 255-276.

MulleR, J. 1964. A palynological contribution to the history of mangrove vegetation in Borneo. In L. M. Cranwell (editor), Ancient Pacific Floras: The Pollen Story. University of Hawaii Press. 1966. Montane pollen from the Tertiary of N.W. Borneo. Blumea 14: 231-235.

1968. Palynology of the Pedawan and Plateau Sandstone formations (Cretaceous-Eocene)

in Sarawak, Malaysia. Micropaleont. 14: 1-37.
1972. Palynological evidence for change in geomorphology, climate, and vegetation in the Mio-Pliocene of Malesia. In P. \& M. Ashton (editors), The Quaternary Era in Malesia. Univ. Hull Dept. Geog. Misc. Ser. No. 13: 6-16.

. 1981. Fossil pollen of extant angiosperms. Bot. Rev. (Lancaster) 47: 1-142.

Mullette, K. J., N. J. Hannon \& A. G. Elliott. 1974. Insoluble phosphorus usage by Eucalyptus. Plant \& Soil 41: 199-205.

Nix, H. 1981. The environment of Terra Australis. In A. Keast (editor), Ecological Biogeography of Australia. Junk, The Hague.

\& J. D. Kalma. 1972. Climate as a dominant control in the biogeography of northern Australia and New Guinea. In D. Walker (editor), Bridge and Barrier: The Natural and Cultural History of Torres Strait. School of Pacific Studies Publ. BG/3. ANU, Canberra. 
Offler, C. E. 1969. The external morphology of extant and fossil vegetative shoots as a basis for palaeobotanical studies. Ph.D. Thesis, Univ. of Adelaide. (Unpubl.).

Ollier, C. P. 1977. Early landform evolution. In C. P. Jeans (editor), Australia: A Geography. University of Sydney Press, Sydney.

OWen, J. A. 1975. Palynology of some Tertiary deposits from New South Wales. Ph.D. Thesis, ANU. (Unpubl.).

PARSONS, R. F. 1968. The significance of growth-rate comparisons for plant ecology. Amer. Naturalist 102: 595-597.

- 1981. Eucalyptus scrubs and shrublands. In R. H. Groves (editor), Australian Vegetation. Cambridge University Press, Cambridge.

Partridge, A. D. 1976. The geological expression of Eustacy in the Early Tertiary of the Gippsland Basin. APEA J. 16: 73-79.

PAtton, R. T. 1958. Fossil wood from Victorian brown coal. Proc. Roy. Soc. Victoria 70: 129_ 143.

Perry, R. A. \& M. Lazarides. 1962. Vegetation of the Alice Springs area. In R. A. Perry (compiler), General Report of Lands of the Alice Springs Area, Northern Territory, 1956-57. CSIRO Land Research Series No. 6.

Pike, K. M. 1953. Fossil fruiting cones of Casuarina and Banksia from Tertiary deposits in Victoria. Proc. Roy. Soc. Victoria 65: 1-8.

Pocknall, D. T. 1981. Pollen and spores from the Rifle Butts Formation (Altonian, Lower Miocene) Otago, New Zealand. New Zealand Geol. Surv. Rept. Palynol. 40.

Powell, C. M. A. \& B. D. Johnson. 1980. Constraints on the position of Sundaland. Tectonophys. 63: 11-109.

— B. D. Johnson \& J. J. VeEvers. 1981. The Early Cretaceous breakup of Eastern Gondwanaland, the separation of Australia and India, and their interaction with Southeast Asia. In A. Keast (editor), Ecological Biogeography of Australia. Junk, The Hague.

Quilty, P. G. 1974. Tertiary stratigraphy of Western Australia. J. Geol. Soc. Austral. 21: 301-318.

2. 1980. Sedimentation cycles in the Cretaceous and Cenozoic of Western Australia. Tectonophys. 63: 349-366.

Raven, P. H. 1973. Evolution of subalpine and alpine plant groups in New Zealand. New Zealand J. Bot. 11: 177-200.

Schmidt, P. W., D. T. Currey \& C. D. Ollier. 1976. Subbasaltic weathering, damsites, palaeomagnetism and the age of lateritisation. J. Geol. Soc. Austral. 23: 367-370.

Scrumm, S. A. 1968. River adjustment to altered hydrologic regimen Murrumbidgee River and Paleochannels, Australia. U.S. Geol. Surv. Prof. Pap. 598: 1-65.

Shackleton , N. J. \& J. P. KennetT. 1975. Palaeotemperature history of the Cenozoic and the initiation of Antarctic glaciation: oxygen and carbon isotope analysis of DSDP sites 277, 279, and 281. Initial Rep. Deep Sea Drill. Proj. 29: 743-755.

Singh, G. A., A. P. Kershaw \& R. Clarke. 1981a. Quaternary vegetation and fire history in Australia. In A. M. Gill, R. A. Groves \& I. R. Noble (editors), Fire and the Australian Biota. Australian Academy of Science, Canberra.

, N. D. Opdyke \& J. M. Bower. 1981b. Late Cainozoic Stratigraphy, Palaeomagnetic Chronology and vegetational history from Lake George, New South Wales. J. Geol. Soc. Austral. 28: $435-452$.

Specht, R. L. 1963. Dark Island Heath (Ninety-mile Plain, South Australia). VII. The effect of fertilizer on composition and growth, 1950-60. Austral. J. Bot. 11: 67-94.

— \& J. S. Womersley. 1979. Heathlands and related shrublands of Malesia (with particular reference to Borneo and New Guinea). Ch. 12 in R. L. Specht (editor), Ecosystems of the World 9A. Heathlands and Related Shrublands, Descriptive Analysis. Elsevier, Amsterdam.

Steenis, van, C. G. G. J. 1979. Plant geography of east Malesia. J. Linn. Soc. Bot. 79: 97-178.

Stover, L. E. \& P. R. Evans. 1973. Upper Cretaceous-Eocene spore-pollen zonation, offshore Gippsland Basin, Australia. Geol. Soc. Austral. Special Publ. 4: 55-72.

\& A. D. PARTRIDGE. 1973. Tertiary and late Cretaceous spores and pollen from the Gippsland Basin, southeastern Australia. Proc. R. Soc. Victoria 85: 237-286.

Townrow, J. A. 1965a. Notes on some Tasmanian pines. I. Some Lower Tertiary podocarps. Pap. \& Proc. Roy. Soc. Tasmania 99: 87-108.

. 1965b. Notes on some Tasmanian pines. II. Arthrotaxis from the Lower Tertiary. Pap. \& Proc. Roy. Soc. Tasmania 99: 109-113.

Traverse, A. 1955. Pollen analysis of the Brandon lignite of Vermont. U.S. Bureau of Mines Report of Investigations 5151.

Vail, P. R., R. M. Mitchum, JR. \& S. Thomson III. 1977. Seismic stratigraphy and global changes of sea level Part 4: Global cycles of relative changes of sea level. In C. E. Payton (editor), Seismic Stratigraphy-Applications to Hydrocarbon Exploration. Memoir 26, American Association of Petroleum Geologist, Tulsa, Oklahoma U.S.A. 
WeBB, L. J. 1959. A physiognomic classification of Australian rainforests. J. Ecol. 47: 551-570. 1978. A general classification of Australian rainforests. Australian Plants 9: 349-363.

\& J. G. TracEY. 1972. An ecological comparison of vegetation communities on each side of Torres Strait. In D. Walker (editor), Bridge and Barrier: The Natural and Cultural History of Torres Strait. Research School of Pacific Studies Dept. Biogeography and Geomorphology Publ. BG/3, Australian National University, Canberra.

\& - 1981a. Australian rainforest: patterns and change. In A. Keast (editor), Ecological Biogeography of Australia. W. Junk, The Hague.

\& 1981 b. The rainforests of Australia. In R. H. Groves (editor), Australian Vegetation. Cambridge University Press, Cambridge.

\& L. W. Jessup. 1982. Recent evidence for autochthony of Australian tropical and subtropical rainforest floristic elements. Submitted for publication, Telopea.

Wellman, P. 1979. On the Cainozoic uplift of the southeastern Australian Highland. J. Geol. Soc. Austral. 26: 1-9.

1980. Reply: on the Cainozoic uplift of southeastern Australian Highland. J. Geol. Soc. Austral. 27: 119.

Williamson, W. H. 1964. The development of ground-water resources of alluvial formations. B11 in Water Resource, Use and Management. Proceedings of Symposium, Australian Academy of Science. Melbourne University Press.

Young, R. W. 1977. Landscape development in the Shoalhaven River Catchment of southeastern New South Wales. Z. Geomorph. N.F. 21: 262-283. 


\section{$2 \mathrm{BHL}$ Biodiversity Heritage Library}

Martin, Helene A. 1982. "Changing Cenozoic Barriers and the Australian Paleobotanical Record." Annals of the Missouri Botanical Garden 69, 625-667. https://doi.org/10.2307/2399086.

View This Item Online: https://www.biodiversitylibrary.org/item/87379

DOI: https://doi.org/10.2307/2399086

Permalink: https://www.biodiversitylibrary.org/partpdf/8268

\section{Holding Institution}

Missouri Botanical Garden, Peter H. Raven Library

\section{Sponsored by}

Missouri Botanical Garden

\section{Copyright \& Reuse}

Copyright Status: In copyright. Digitized with the permission of the rights holder.

License: http://creativecommons.org/licenses/by-nc-sa/3.0/

Rights: https://biodiversitylibrary.org/permissions

This document was created from content at the Biodiversity Heritage Library, the world's largest open access digital library for biodiversity literature and archives. Visit BHL at https://www.biodiversitylibrary.org. 